\title{
PEMANFAATAN MULTIMEDIA INTERAKTIF PEMBELAJARAN IPA-BIOLOGI TERHADAP MOTIVASI DAN KEMAMPUAN KOGNITIF SISWA SMP NEGERI 14 KOTA PALEMBANG
}

\author{
Tri Pradnya Parata \\ SMP Negeri 14 Palembang \\ M. Zawawi \\ Program Magister Universitas Indo Global Mandiri
}

\begin{abstract}
ABSTRAK
The research was aimed to know the effect of multimedia interaktive towards learning achievement and student's learningactivities. The research was held in public junior high school 14 palembang with the research sample is students of class $\mathrm{VII}_{8}$ and $\mathrm{VII}_{9}$ as experiment class and students at class $\mathrm{VII}_{10}$ and $\mathrm{VII}_{11}$ as control class. Scheme used in this research is a Quasi-experimental scheme with research design pretest-postest nonequivalen group design. This research shows that there is a different study motivation which are not significant between students used interactive multimedia with they who got learning through conventional strategy. The other result shows that there is a different cognitive study result which is significant between students used multimedia interactive with they who got Learning through conventional strategy.It is expected that multimedia interactive can be used as an alternative to biology learning in addtion to other learning media.
\end{abstract}

Keywords: Interactive Multimedia, Motivation, Cognitive ability

\section{PENDAHULUAN}

\subsection{Latar Belakang Penelitian}

Menurut Rencana Strategis Kemendiknas Tahun 2010-2014 Bab IV tentang Penguatan dan Perluasan Pemanfaatan TIKdi Bidang Pendidikan maka penguatan pemanfaatan TIK untuk pembelajaran, manajemen dan layanan di lakukan melalui kebijakan - kebijakan antara lain (1) Penyedian sarana dan prasarana TIK serta muatan pembelajaran berbasis TIK untuk penguatan dan perluasan pembelajaran pada semua jenjang pendidikan, (2) Pengembangan pusat sumber belajar berbasis TIK Pada pendidikan dasar dan menengah, Dan (3) Peningkatan kemampuan SDM untuk Mendukung pendayagunaan TIK di pusat dan di daerah. Berdasarkan kebijakan diatas, maka guru atau pengajar dituntut untuk dapat menggembangkan sumber belajar berbasis TIK.
Tabel. 1.1

Jumlah dan pendidikan guru di SMPNegeri 14 Palembang

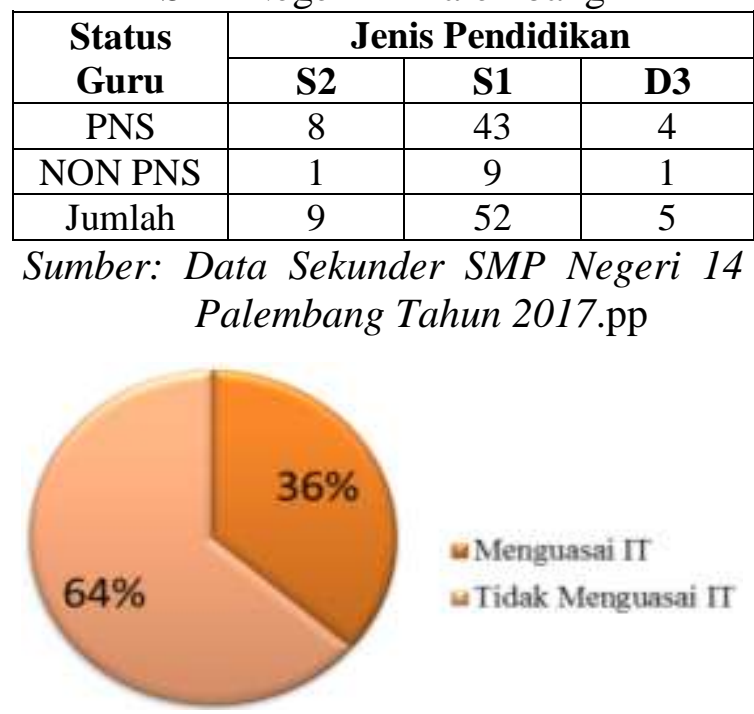

Gambar 1.1 Presentase Guru di SMPNegeri 14 Palembang yang menguasai IT Tahun 2017

Berdasarkan datadiatas dan wawancara dari guru- guru berjumlah 66 orang diperoleh 42 orang $(64 \%)$ yang sudah menguasai IT, namun dalam proses 
pembelajaran belum banyak yang menggunakan media pembelajaran yang berbasis Information Tecnology (IT) dengan alasan keterbatasan jumlah Multimedia yang dapat digunakan di kelas, hanya tersedia satu ruang Multimedia yang dapat digunakan.

Pendekatan Inkuari banyak disarankan dalam pembelajaran IPA, namun pada kenyataan pembelajaran IPA masih kental dengan pendekatan tradisional,yang dicirikan dengan tranmisi informasi dan belajar menerima (Passive Learning) model pembelajaran yang digunakan masih berupa model pembelajaran langsung (Direc Learning) yang lebih mengarahkan pada pemberian informasi (ceramah) Siswa hanya berperan sebagai objek belajar dan guru terkesan sebagai seorang informan. Metode ceramah menyebabkan siswa menjadi malas untuk mempelajari biologi, terutama materi yang tidak dimengerti dan tidak dipaham. Masalah lain terjadi ketika guru sulit dalam menjelaskan materi biologi mengenai kejadian yang berkaitan dengan alam sekitar yang prosesnya sulit untuk diamati secara langsung, misalnya tentang sistem tranformasi energi pada tumbuhan (fotosintesis). Materi sistem tranformasi energi pada tumbuhan sebagian bersifat abstrak karena terjadi didalam tubuh tumbuhan, sehingga perlu adanya media yang dapat membantu menjelaskan konsep fotosintesis.

Berdasarkan observasi dari guru IPA di SMP Negeri14 Palembang, strategi yang sering digunakan pada kelas eksperimen yaitu ceramah, kerja mandiri, diskusi kelompok, diskusi kelas, Namun hasil dari penerapan stratgi belajar tersebut kurang optimal. Hal ini dapat dilihat dari kurangnya keaktifan siswa pada saat diskusi kelompok, mereka takut salah ketika berpendapat, kurang interaktif dalam pembelajaran, mereka cepat bosan karena kebanyakan materi kelas VII adalah materi yang sulit diamati secara langsung seperti sistem tranformasi energi pada makhluk hidup, sitem pernapasan, sistem pencernaan, system organisasi makhluk hidup. Dengan demikian ketika mereka termotivasi untuk belajar mereka cendrung tidak mendapatkan informasi yang memperjelas keabstrakan proses materi yang sedang dipelajari. .Akibatnya bagi siswa mereka cepat merasa bosan, sehingga pembelajaran yang dilakukan dinilai kurang menarik bagi siswa. Jika motivasi sudah mengalami penurunan, maka dampak yang nyata terlihat pada hasil belajar siswa.

Menurut peraturan mentri pendidikan dan kebudayaan RI. (2014; No.104,pasal 1, No.3) Ketuntasan belajar merupakan tingkat minimal pencapaian kompetensi sikap pengetahuan dan ketrampilan meliputi ketuntasan penguasaan substansi dan ketuntasan belajar dalam konteks kurun waktu belajar.

Hal ini semakin diperkuat dari hasil observasi di SMP 14 Palembang, diperoleh informasi bahwa pada tahun ajaran 20152016 pengguasaan siswa pada materi fotosintesis masih dibawah Kriteria Ketuntasan Minimal (KKM) yang telah ditetapkan yaitu 75, dengan persentase siswa yang belum memenuhi KKM lebih dari $50 \%$. Upaya yang pernah dilakukan oleh guru agar pembelajaran di kelas menjadi menyenangkan adalah dengan menggunakan media gambar untuk memperjelas materi yang sulit diamati serta melakukan diskusi kelompok dan diskusi kelas guru juga memberikan penguatan materi dan siswa membuat catatan. Tetapi hal ini ternyata masih belum dapat membuat siswa terdorong untuk belajar dengan baik karena respon balik siswa yang kurang terlihat,siswa cendrung diam dan takut salah dalam menjawab pertanyaan dari guru.

Berdasarkan permasalahan tersebut maka guru SMP Negeri 14 Palembang bermaksud melakukan penelitian,Media yang ditawarkan untuk mengatasi kesulitan siswa dalam mempelajari system tranformasi energi pada tumbuhan adalah dengan menggunakan Multimedia Interaktif. Penggunaan Multimedia dapat 
membantu guru dan peserta didik dalam memahami materi pembelajaran. Ketepatan memilih media merupakan faktor utama dalam mengoptimalkan hasil pembelajaran. Untuk memilih yang tepat seorang guru perlu mempertimbangkan berbagai landasan agar media yang dipilih benar - benar sesuai dengan tingkat pemahaman, kemampuan berpikir, psikologis dan kondisi sosial peserta didik. Salah satu media yang dapat memotivasi peserta didik untuk belajar karena kegiatan pembelajaran akan lebih menarik,efektif, efisien, dan menyenangkan adalah dengan menggunakan Multimedia.

Menurut Haffost dalam Rusman (2012; 149), Multimedia dapat definisikan sebagai suatu system komputer yang terdiri dari hardware dan software yang memberikan kemudahan untuk menggabungkan gambar, video, fotografi, dan animasi dengan suara, teks, dan data yang dikendalikan dengan program komputer. Menurut Daryanto (2016: 70) Secara umum manfaat pembelajaran dengan menggunakan Multimedia proses pembelajaran lebih menarik, lebih interaktif, jumlah waktu mengajar dapat dikurangi, kualitas belajar peserta didik dapat ditingkatkan dan proses pembelajaran dapat dilakukan dimana dan kapan saja, serta sikap belajar peserta didik dapat ditingkatkan.

Menurut Miftahudin (281) Kelebihan Multimedia adalah menarik indera dan menarik minat, karena merupakan gabungan antara pandangan, suara, dan Gerakkan. Lembaga riset dan penerbitan computer yaitu Computer Technology Researh (CTR) menyatakan bahwa orang mampu mengingat $20 \%$ dari yang dilihatnya, $30 \%$ dari yang didengar,tetapi orang dapat mengingat $50 \%$ dari yang dilihat dan didengar, dan $70 \%$ dari yang dilihat, didengar dan dilakukan sekaligus maka Multimedia sangat efektif menjadi alat yang ampuh untuk pengajar.

\subsection{Identifikasi Masalah}

a. Pembelajaran konvensional yang menggunakan metode ceramah dan media yang digunakan berupa gambar diam lebih cendrung membosankan dan kurang interaktif dan komunikatif dalam mentransfer pengetahuan.

b. Dengan memperhatikan kompleks dan uniknya proses belajar, maka Ketepatan pemilihan metode dan media pembelajaran akan sangat berpengaruh terhadap hasil belajar.

c. Salah satu media yang dapat memotivasi pesertadidik untuk belajar adalah Multimedia interaktif, tetapi sejauh ini guru belum banyak menggunakan.

d. Penguasaan dan aktivitas penggunaan metode dan media pembelajaran oleh guru belum optimal, sehingga terkesan monoton, kurang variatif dan inovatif.

e. Strategi mengajar yang monoton dan tidak bervariasi menyebabkan rendahnya motivasi belajar siswa.

\subsection{Perumusan Masalah}

a. Apakah Multimedia interaktif berpengaruh terhadap motivasi siswa?

b. Apakah Multimedia interaktif berpengaruh terhadap kemampuan kognitifsiswa?

c. Apakah Multimedia interaktif dan motivasi berpengaruh terhadap kemampuan kognitif siswa?

\subsection{Tujuan Penelitian}

Secara umum penelitian ini bertujuan untuk memproleh gambaran mengenai. Pengaruh pemanfaatan Multimedia interaktif terhadap motivasi dan kemampuan kognitif siswa di SMP Negeri 14 Palembang. Adapun tujuan khusus penelitian ini adalah sebagai berikut:

a. Untuk mengetahui pengaruh pemanfaatan Multimedia interaktif pembelajaran IPA-Biologi terhadap 
motivasi belajar siswa di SMP Negeri 14 Palembang.

b. Untuk mengetahui pengaruh pemanfaatan Multimedia interaktif Pembelajaran IPA-Biologi terhadap kemampuan kognitif siswa di SMP Negeri 14 Palembang.

c. Untuk mengetahui pengaruh pemanfaatan Multimedia interaktif, motivasi terhadap kemampuan kognitif siswa di SMP Negeri 14 Palembang.

\subsection{Kegunaan Penelitian}

Hasil penelitian ini diharapkan dapat memberi sumbangan dan manfaat yaitu:

1. Secara teoritis, hasil penelitian ini diharapkan dapat memberikan manfaat bagi beberapa pihak, antara lain bagi guru, sekolah, dan Dinas Pendidikan dan Kebudayaan Kota Palembang.

2. Secara praktis, hasil penelitian ini diharapkan dapat memberi sumbangan terhadap pengembangan ilmu pendidikan pada umumnya, dan diharapkan dapat membantu guru dalam medesain pembelajaran secara kreatif.

\section{KAJIAN PUSTAKA}

\subsection{Tinjauan Teori}

Dalam tinjauan teori ini penulis sajikan seperangkat konsep dan teori untuk menjelaskan variable-variabel Multimedia interaktif, motivasi dan kemampuan kognitif siswa. Selanjutnya disusun kerangka pikir penelitian dan rumusan hipotesis mengenai keterkaitan antar variabel tersebut.

\subsubsection{Media Pembelajaran}

Kata media merupakan bentuk jamak dari kata medium. Medium dapat didefenisikan sebagai perantara atau pengantar terjadinya komunikasi dari pengirim menuju penerima (Ibrahim, et.al,
2001) Media pembelajaran yakni media yang digunakan sebagai alat dan bahan kegiatan pembelajaran.

Fungsi dan Manfaat Media Pembelajaran dalam proses pembelajaran, media memiliki fungsi sebagai pembawa informasi dari sumber yaitu guru atau pendidik menuju penerima yaitu siswa atau peserta didik (Daryanto, 2016) Sedangkan manfaat media adalah

a. Memperjelas pesan agar tidak terlalu verbalitas

b. Mengatasi keterbatasan ruang, waktu tenaga dan daya indra

c. Menimbulkan gairah belajar, interaksi lebih langsung antara murid dengan pengajar.

d. Memungkinkan anak belajar mandiri sesuai dengan bakat dan kemampuan visual, auditori dan kinestetiknya.

e. Memberi rangsangan yang sama, mempersamakan pengalaman dan menimbulkan persepsi yang sama.

f. Proses pembelajaran mengandung lima komponen, komunikasi, guru, bahan pembelajaran, media pembelajaran, siswa dan tujuan pembelajaran.

Jadi media pembelajaran adalah segala sesuatu yang dapat digunakan untuk menyalurkan pesan, sehingga dapat merangsang perhatian, minat, pikiran, dan perasaan siswa dalam kegiatan belajar untuk mencapai tujuan belajar.

\subsubsection{Landasan Penggunaan Media Pembelajaran}

Landasan filosofis, adalah suatu pandangan bahwa dengan digunakannya berbagai media hasil teknologi baru di dalam kelas, akan berakibat proses pembelajaran kurang manusiawi. Bukankah dengan adanya berbagai media pembelajaran justru siswa dapat mempunyai banyak pilihan untuk digunakan media yang lebih sesuai dengan karateristik pribadinya, dengan kata lain siswa dihargai harkat kemanusiannya diberi kebebasan untuk menentukan 
pilihan, baik cara maupun alat belajar sesuai dengan kemampuannya, dengan demikian penerapan teknologi tidak berarti dehumanisasi.

Landasan psikologis, Dengan memperhatikan kompleks dan uniknya proses belajar maka ketepatan pemilihan media dan metode pembelajaran akan sangat berpengaruh terhadap hasil belajar peserta didik. Di samping itu persepsi peserta didik juga sangat mempengaruhi hasil belajar. Oleh sebab itu dalam pemilihan media di samping memperhatikan kompleksitas hendaknya diupayakan secara optimal agar proses pembelajaran dapat berlangsung secara efektif, untuk maksud tersebut perlu diadakan pemilihan media yang tepat sehingga dapat menarik perhatian peserta didik serta memberikan kejelasan objek yang diamatinya. Bahan Pembelajaran yang akan diajarkan disesuaikan dengan pengalaman peserta didik.

Kajian psikologis menyatakan bahwa anak akan lebih mudah mempelajari hal yang konkrit dari pada yang abstrak. Landasan teknologis, Teknologi pembelajaran adalah teori dan praktek perancangan, pengembangan, penerapan, pengelolaan, dan penilaian proses dan sumber belajar. Jadi teknologi pembelajaran merupakan proses komplek dan terpadu yang melibatkan orang, prosedur, ide, peralatan dan oganisasi untuk menganalis, mencari pemecahan masalah, melaksanakan, mengevaluasi dan mengelola pemecahan masalah - masalah dalam situasi kegiatan belajar itu mempunyai tujuan dan terkontrol.

Landasan empiris, Temuan - temuan penelitian menunjukkan bahwa terdapat interaksi antara penggunaan media pembelajaran dan karateristik belajar peserta didik dalam menentukan hasil belajar peserta didik. Artinya peserta didik akan mendapat keuntungan yang signifikan bila ia belajar dengan menggunakan media yang sesuai dengan karakteristik tipe belajar visual akan lebih memproleh keuntungan bila pembelajaran menggunakan media visual, seperti gambar, diagram, video, atau film. Sementara peserta didik yang memiliki tipe belajar auditif akan lebih suka belajar dengan media audio,seperti radio, rekaman suara, atau ceramah guru. Akan lebih menguntungkan peserta didik dari kedua tipe belajar tersebut jika menggunakan media audio-visual.

Berdasarkan landasan rasional empiris tersebut maka pemilihan media pembelajaran hendaknya jangan atas dasar kesukaan guru tetapi harus mempertimbangkan kesesuaian antara karateristik pembelajaran, karateristik materi pelajaran dan karakteristik media itu sendiri.

\subsubsection{Multimedia Interaktif}

Menurut Daryanto (2016) Multimedia interaktif adalah suatu Multimedia yang dilengkapi dengan alat pengontrol yang dapat dioprasikan oleh pengguna, sehingga pengguna dapat memilih apa yang dikehendaki untuk proses selanjutnya diartikan sebagai proses penciptaan lingkungan yang memungkinkan terjadinya proses belajar. Jadi dalam pembelajaran yang utama adalah bagaimana siswa belajar. Belajar dalam pengertian aktifitas mental siswa dalam berinteraksi dengan lingkungan yang menghasilkan perubahan perilaku yang bersifat relative konstan .Dengan demikian aspek yang menjadi penting dalam aktifitas belajar adalah lingkungan. Bagaimana lingkungan ini diciptakan dengan menata unsur - unsurnya sehingga dapat mengubah perilaku siswa.

Dari uraian di atas, apabila kedua konsep tersebut kita gabungkan maka Multimedia pembelajaran dapat diartikan sebagai aplikasi Multimedia yang digunakan dalam proses pembelajaran, dengan kata lain untuk menyalurkan pesan berupa pengetahuan, keterampilan dan sikap serta dapat merangsang pikiran, perasaan, perhatian dan kemauan siswa sehingga secara sengaja proses belajar terjadi, bertujuan dan terkendali. Dengan 
demikian Multimedia pembelajaran interaktif adalah media yang dirancang agar siswa dapat belajar secara mandiri, aktif dan terkendali. Menurut Arsyad (2010) Multimedia interaktif adalah salah satu media yang dapat dijadikan bahan ajar yang merupakan gabungan dari teks, suara, gambar, animasi dan warna dimana pengguna mendapatkan keleluasan dalam mengontrol Multimedia tersebut.

\subsubsection{Kelebihan Multimedia pembelajaran interaktif dibanding media yang lain:}

1. Memperbesar benda yang sangat kecil dan tidak tampak oleh mata. Dengan Multimedia maka dapat ditampilkan benda-bendaseperti kuman, bakteri, elektron, dll. dengan demikian benda-benda tersebut akan mudah dipahami oleh siswa.

2. Memperkecil benda yang sangat besar, yang tidak mungkin dihadirkan di sekolah. Dengan demikian kita dapat menyajikan benda - bendaseperti gedung, gajah, gunung, candi, rumah, dll. Sehingga memudahkan guru dalam menyampaikan materi secara riil melaui gambar, movie atau animasi.

3. Menyajikan benda atau peristiwa yang kompleks, rumit, dan berlangsung cepat atau lambat. Adanya kemampuan ini maka guru dapat menyajikan melaui gambar animasi atau movie tentang susunan atom, sistem tubuh manusia, bekerjanya suatu mesin, beredarnya planet-planet, berkembangnya bunga, dll.

4. Menyajikan suatu benda atau peristiwa yang jauh, melalui Multimedia maka guru dapat menghadirkan obyek-obyek seperti planet, bulan, bintang, salju ke dalam ruang kelas.

5. Menyajikan benda atau peristiwa yang berbahaya. Dengan kemampuan ini maka guru dapat menyajikan peristiwa-peristiwa yang berbahaya seperti ledakan bom, peluncuran roket, letusan gunung berapi, kebakaran, binatang buas, racun, dll.

6. Meningkatkan daya tarik dan perhatian siswa. Dengan kemampuan ini maka pembelajaran dapat berlangsung secara menarik dan meningkatkan motivasi belajar siswa.

\subsubsection{Karakteristik media dalam Multimedia pembelajaran}

Sebagai salah satu komponen sistem pembelajaran, pemilihan dan penggunaan Multimedia pembelajaran harus memperhatikan karakteristik komponen lain, seperti: tujuan, materi, stategi dan juga evaluasi pembelajaran.

Karakterisik Multimedia pembelajaran adalah sebagai berikut.

1. Memiliki lebih dari satu media yang konvergen, misalnya menggunakan unsur audio dan visual.

2. Bersifat interaktif, dalam pengertian memiliki kemampuan untuk mengakomodasi respon pengguna.

3. Bersifat mandiri, dalam pengertian memberi kemudahan dan kelengkapan isi sedemikian rupa sehinggga pengguna bisa menggunakan tanpa bimbingan orang lain.

Selain memenuhi ketiga karakteristik tersebut, mutimedia pembelajaran sebaiknya juga memenuhi fungsi sebagai berikut.

1. Mampu memperkuat respon pengguna secepatnya dan sesering mungkin

2. Mampu memberikan kesempatan kepada siswa untuk mengontrol laju kecepatan belajarnya sendiri.

3. Memperhatikan bahwa siswa mengikuti suatu urutan yang jelas dan terkendalikan. 
Mampu memberikan kesempatan adanya partisipasi dari pengguna dalam bentuk respon, baik berupa jawaban, pemilihan, keputusan, percobaan dan lain-lain.

\subsubsection{Dampak \\ MultimediaPembelajaran interaktif}

Tidak dapat disangka bahwa terpaan teknoologi berupa perangkat lunak (Software) maupun perangkat keras (hardware) sudah sekian menyatu dengan kehidupan manusia modern. Dalam bidang pembelajaran, kehadiran media pembelajaran misalnya sudah dirasakan banyak membantu tugas guru dalam mencapai tujuan pembelajaranya. Dalam era teknologi dan informasi ini, pemanfaatan kecanggihan teknologi untuk kepentingan pembelajaran sudah bukan merupakan hal yang baru lagi. Salah satu media pembelajaran baru yang akhir-akhir ini semakin menggeserkan peran guru hidup adalah teknologi Multimedia yang tersedia melalui perangkat komputer.

Dengan teknologi ini, kita bisa belajar apa saja, kapan saja dan dimana saja. Di Indonesia, meskipun teknologi ini belum digunakan secara luas namun cepat atau lambat teknologi ini akan diserap juga ke dalam system pembelajaran disekolah.

Menurut Mc. Donald dalam Djamarah, (2008: 148) yang mengatakan bahwa motivasi adalah suatu perubahan energi di dalam pribadi seseorang yang ditandai dengan timbulnya afektif (perasaan) dan reaksi untuk mencapai tujuan. Perubahan energi dalam diri seseorang itu dapat berbentuk suatu aktivitas nyata berupa kegiatan fisik. Oleh karena seseorang mempunyai tujuan dalam aktivitasnya, maka seseorang mempunyai motivasi yang kuat untuk mencapainya dengan segala upaya yang dapat dia lakukan.

Woodworth dan Marques (Sunarto, 2008), mendefinisikan motivasi sebagai satu set motif atau kesiapan yang menjadikan individu cenderung melakukan kegiatan-kegiatan tertentu dan untuk mencapai tujuan-tujuan tertentu. Pendapat tersebut senada dengan yang disampaikan oleh Chung dan Meggison (Suhaimin), yang mendefinisikan motivasi sebagai prilaku yang ditujukan kepada sasaran, motivasi berkaitan dengan tingkat usaha yang dilakukan oleh seseorang dalam mengejar suatu tujuan. Motivasi berkaitan erat dengan kepuasan pekerjaan.

Menurut Dalyono (2009: 57), motivasi adalah daya penggerak atau pendorong untuk melakukan sesuatu pekerjaan. Sumiati (2007: 236), mengatakan bahwa motivasi adalah dorongan yang muncul dari dalam diri sendiri untuk bertingkah laku. Dorongan itu pada umumnya diarahkan untuk mencapai sesuatu tujuan. Sehingga motivasi dapat memberikan semangat yang luar biasa terhadap seseorang untuk berprilaku dan dapat memberikan arah dalam belajar. Motivasi ini pada dasarnya merupakan keinginan yang ingin dipenuhi (dipuaskan), maka iaakan timbul jika ada rangsangan, baik karena adanya kebutuhan maupun minat terhadap sesuatu.

Menurut Sardiman (2007), Motivasi adalah perubahan energi seseorang yang ditandai dengan munculnya "feeling" dan Didahului dengan tanggapan terhadap adanya tujuan.

Menurut Djamarah (2008), motivasi adalah suatu perubahan energi didalam peribadi seseorang yang ditandai dengan timbulnya efeltif (perasaan) dan reaksi untuk mencapai tujuan.

Menurut Uno (2006) motivasi adalah proses psikologis yang dapat menjelaskan perilaku seseorang, motivasi merupakan kekuatan yang mendorong seseorang melakukan sesuatu untuk mencapai tujuan. Kekuatan-kekuatan ini pada dasarnya dirangsang oleh adanya berbagai macam kebutuhan, seperti: keinginan yang hendak dipenuhinya, tingkah laku, tujuan, umpan balik. Atau dapat digambarkan sebagai produk motivasi dasar (Basic Motivations Process) seperti berikut. 


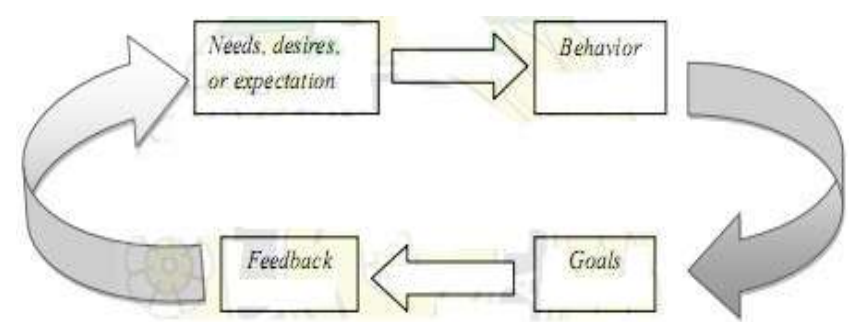

Gambar 2.1 Skema Proses Motivasi

Dasar

Menurut Mc.Clelland, dalam Astaqauliyah, (2006) jika seseorang memiliki motivasi berprestasi maka ia akan berusaha untuk mengungguli orang lain, berprestasi sesuai dengan standar, dan berjuang untuk sukses. Mereka juga mempunyai hasrat untuk melakukan sesuatu dengan lebih baik atau efisien daripada yang dilakukan sebelumnya.

Dari defenisi diatas dapat disimpulkan bahwa motivasi adalah sesuatu yang bersifat dinamis dan merupakan suatu proses yang dapat menampilkan perilaku untuk mencapai tujuan dalam memuaskan kebutuhan-kebutuhan dirinya, sehingga dapat mendapatkan tujuan yang dikehendaki dan dapat selaras dengan waktu yang ada.

\subsubsection{Teori motivasi}

a. Teori Kebutuhan Maslow

Salah satu teori motivasi yang terkenal kegunaannya untuk menerangkan motivasi adalah yang dikembangkan oleh Maslow. Maslow percaya bahwa tingkah laku manusia dibangkitkan dan diarahkan oleh kebutuhan-kebutuhan tertentu yang dibagi dalam 7 kategori, yakni :

1. Fisiologismerupakan kebutuhan manusia yang paling dasar, meliputi kebutuhan akan makanan, pakaian, tempat berlindung, yang penting untuk mempertahankan hidup.

2. Rasa aman Kebutuhan kepastian keadaan dan lingkungan, ketidakpastian, ketidakadilan, keterancaman, akan menimbulkan kecemasan dan ketakutan pada diri individu.

3. Rasa cinta
Merupakan afeksi dan pertalian dengan orang lain.

4. Penghargaan

Kebutuhan rasa berguna, penting, dihargai, dikagumi, dihormati oleh orang-orang lain. Secara tidak langsung ini merupakan kebutuhan perhatian, ketenaran, status, martabat, dan lain sebagainya.

5. Aktualisasi diri

Kebutuhan manusia untuk mengembangkan diri sepenuhnya, merealisasikan potensipotensi yang dimilikinya.

6. Mengetahui dan mengerti

Kebutuhan manusia untuk memuaskan rasa ingin tahunya, untuk mendapatkan pengetahuan, untuk mendapatkan keterangan-keterangan, dan untuk mengerti sesuatu

7. Kebutuhan estetik

Kebutuhan akan keteraturan, keseimbangan, dan kelengkapan dari suatu tindakan (Slameto, 2003).

\subsubsection{Motivasi Belajar}

Motivasi dan belajar merupakan dua hal yang saling mempengaruhi. Siswa akan giat belajar jika ia mempunyai motivasi untuk belajar. Thorndike (Uno, 2011: 11), mendefinisikan belajar sebagai proses interaksi antara stimulus (yang mungkin berupa pikiran, perasaan, atau gerakan) dan respon. Pengertian ini senada dengan pendapat Good dan Brophy (Uno, 2011: 15), yang menyatakan bahwa belajar merupakan suatu proses atau interaksi yang dilakukan seseorang dalam memperoleh sesuatu yang baru dalam bentuk perubahan perilaku sebagai hasil dari pengalaman belajar. Perubahan tingkah laku tersebut tampak dalam penguasaan siswa pada pola-pola tanggapan (respon) baru terhadap lingkungannya yang berupa keterampilan (skill), pengetahuan (knowledge), sikap atau pendirian (attitude), kemampuan 
(ability), pemahaman (understanding), emosi (emotion), apresiasi, jasmani, budi pekerti, serta hubungan sosial.

James O. Whittaker (dalam Djamarah, 2008: 12) merumuskan belajar sebagai suatu proses di mana tingkah laku ditimbulkan atau diubah melalui latihan atau pengalaman. Cronbach (dalam Djamarah, 2008: 13) juga mendefinisikan belajar sebagai suatu aktivitas yang ditunjukkan oleh perubahan tingkah laku sebagai hasil dari pengalamannya. Pendapat yang sama juga disampaikan oleh Howard L. Kingskey dalam Djamarah, (2008: 13) yang mengatakan bahwa belajar adalah proses di mana tingkah laku ditimbulkan atau diubah melalui praktek atau latihan.

Pendapat lain tentang definisi belajar dikemukakan oleh Briggs dalam Sumiati, (2007: 40) yang mengatakan bahwa belajar merupakan suatu proses terpadu yang berlangsung di dalam diri seseorang dalam upaya memperoleh pemahaman dan struktur kognitif baru, atau untuk mengubah pemahaman dan struktur kognitif lama. Memperoleh pemahaman berarti menangkap makna atau arti dari suatu obyek atau situasi yang dihadapi. Sedangkan struktur kognitif adalah persepsi atau tanggapan seseorang tentang keadaan dalam lingkungan sekitarnya yang mempengaruhi ide-ide, perasaan, tindakan dan hubungan sosial orang yang bersangkutan.

Dalam proses belajar, motivasi sangat diperlukan. Menurut Hamalik (2011: 161) motivasi sangat menentukan tingkat berhasil atau gagalnya perbuatan belajar siswa. belajar tanpa adanya motivasi kiranya akan sangat sulit untuk berhasil. Sebab, seseorang yang tidak mempunyai motivasi dalam belajar, tidak akan mungkin melakukan aktivitas belajar. Hal ini merupakan pertanda bahwa sesuatu yang akan dikerjakan itu tidak menyentuh kebutuhannya. Segala sesuatu yang menarik minat orang lain belum tentu menarik minat yang lain selama sesuatu itu tidak bersentuhan dengan kebutuhannya (Djamarah, 2008: 148).

Menurut Kellough dalam Sumarno, (2011) dalam kegiatan belajar mengajar, peran guru yang sangat penting dalam mendorong pembelajaran siswa adalah meningkatkan keinginan siswa atau motivasi siswa untuk belajar. Dalam melakukan tugas tersebut, guru perlu memahami siswa dengan baik agar nantinya guru mampu menyediakan pengalaman-pengalaman pembelajaran, yang darinya siswa menemukan sesuatu yang menarik, bernilai, dan secara intrinsik memotivasi, menantang, dan berguna bagi mereka. McCarty dan Siccone (dalam Sumarno, 2011) menjelaskan bahwa semakin baik guru memahami minat-minat siswa, dan menilai tingkat keterampilan siswa, maka semakin efektif dan menjangkau mengajari mereka.

Guillaume (dalam Sumarno, 2011) menjelaskan bahwa agar siswa termotivasi dalam belajar, guru harus meyakinkan kepada siswa bahwa kita terlibat bersama mereka di setiap tantangan dan berada dalam "sudut mereka" di setiap saat. Hal ini tentunya membutuhkan strategi organisasional dan personal yang fokus pada nilai dan kekuatan motivasi instrinsik dan dampak positifnya pada prestasi akademik siswa. Sulit bagi siswa untuk berhasil jika mereka kekurangan motivasi untuk tetap fokus pada tugas-tugas yang menantang.

Untuk itu, sebelum pelaksanaan proses pembelajaran di kelas dilakukan, seorang guru terlebih dahulu harus menata, mengorganisasikan isi pembelajaran yang akan diajarkan. Hal ini perlu dilakukan agar isi pembelajaran yang diajarkan mudah dipahami siswa. Demikian pula selama proses pembelajaran, guru diharapkan mampu menumbuhkan, menjaga / mempertahankan, dan meningkatkan motivasi belajar siswa, karena dalam proses pembelajaran guru tidak hanya memperhatikan metode dan media pembelajaran saja tetapi guru juga harus berusaha untuk selalu menjaga dan 
meningkatkan motivasi belajar siswa dalam proses pembelajaran.

Menurut De Decce dan Grawford (dalam Djamarah, 2008: 169), ada empat fungsi guru sebagai pengajar yang berhubungan dengan cara pemeliharaan dan peningkatan motivasi belajar siswa, yaitu: (1) guru harus menggairahkan peserta didik, artinya guru harus menghindari hal-hal yang monoton dan membosankan dalam pembelajaran, (2) memberikan harapan realistis, artinya guru harus memelihara harapan-harapan siswa yang realistis dan memodifikasi harapanharapan yang kurang atau tidak realistis, (3) memberikan insentif, artinya guru diharapkan memberikan hadiah kepada siswa (dapat berupa pujian, angka yang baik, dan sebagainya) atas keberhasilannya, sehingga siswa terdorong untuk melakukan usaha lebih lanjut guna mencapai tujuan pembelajaran, mengarahkan perilaku siswa, artinya guru harus memberikan respon terhadap siswa yang tidak terlibat secara langsung dalam pembelajaran agar berpartisipasi aktif.

Motivasi belajar penting bagi guru dan siswa. Biggs dan Telfer (dalam Dimyati, 2009: 84) menjelaskan bahwa motivasi belajar dan motivasi bekerja perlu dimiliki oleh siswa, dan guru dituntut untuk memperkuat motivasi siswa.

Pentingnya motivasi belajar bagi siswa adalah sebagai berikut: (1) menyadarkan kedudukan pada awal belajar, proses dan hasil akhir, (2) menginformasikan tentang kekuatan usaha belajar yang dibandingkan dengan teman sebaya, (3) mengarahkan kegiatan belajar, (4) membesarkan semangat belajar, (5) menyadarkan tentang adanya perjalanan belajar dan kemudian bekerja. Kelima hal tersebut menunjukkan pentingnya motivasi tersebut disadari oleh pelakunya sendiri. Bila motivasi disadari oleh pelaku, maka suatu pekerjaan, dalam hal ini tugas belajar akan terselesaikan dengan baik.

Bagi guru, pentingnya pengetahuan dan pemahaman tentang motivasi belajar siswa (dalam Dimyati, 2009: 85) antara lain bermanfaat: (1) membangkitkan, meningkatkan, dan memelihara semangat siswa untuk belajar sampai berhasil, (2) mengetahui dan memahami motivasi belajar siswa di kelas bermacam-macam, (3) meningkatkan dan menyadarkan guru untuk memilih salah satu diantara peran seperti sebagai penasehat, fasilitator, teman diskusi, atau pendidik, (4) memberi peluang guru untuk unjuk kerja rekayasa pedagogis. Dengan demikian guru dapat berupaya membuat siswa yang acuh tak acuh dalam belajar menjadi siswa yang tekun dan penuh semangat.

Tabel 2.1 Beberapa Pendapat Teori Belajar

\begin{tabular}{|c|c|c|}
\hline $\begin{array}{l}\text { JEAN } \\
\text { PIAGET }\end{array}$ & $\begin{array}{l}\text { JEROME } \\
\text { BRUNER }\end{array}$ & $\begin{array}{l}\text { DAVID } \\
\text { AUSUBEL }\end{array}$ \\
\hline $\begin{array}{l}\text { - Proses belajar } \\
\text { terjadi } \\
\text { menurut pola } \\
\text { tahap - tahap } \\
\text { perkembangan } \\
\text { tertentu } \\
\text { sesuai dengan } \\
\text { umur siswa. } \\
\text { - Proses belajar } \\
\text { melalui tahap } \\
\text { - tahap } \\
\text { Asimilasi } \\
\text { (proses } \\
\text { penyesuaian } \\
\text { pengetahuan } \\
\text { baru dengan } \\
\text { struktur } \\
\text { kognitif } \\
\text { siswa). } \\
\text { Akomodasi } \\
\text { (proses } \\
\text { penyesuaian } \\
\text { struktur } \\
\text { kognitif siswa } \\
\text { dengan } \\
\text { pengetahuan } \\
\text { baru). } \\
\text { Ekuilibrasi } \\
\text { (proses } \\
\text { penyeimbang } \\
\text { an mental } \\
\text { setelah terjadi } \\
\text { proses } \\
\text { asimilasi } \\
\text { /akomodasi). }\end{array}$ & $\begin{array}{l}\text { - Proses belajar } \\
\text { terjadi } \\
\text { lebih ditentukan } \\
\text { oleh cara kita } \\
\text { mengatur materi } \\
\text { pelajaran, dan } \\
\text { bukan ditentukan } \\
\text { oleh umur siswa. } \\
\text { - Proses belajar } \\
\text { melalui tahap - } \\
\text { tahap : } \\
\text { Enaktif } \\
\text { (aktivitas siswa } \\
\text { untuk memahami } \\
\text { lingkungan. } \\
\text { Ikonik (siswa } \\
\text { melihat dunia } \\
\text { melalui gambar } \\
\text { gambar dan } \\
\text { visualisasi } \\
\text { verbal). } \\
\text { Simbolik (siswa } \\
\text { memahami } \\
\text { gagasan } \\
\text { gagasan abstrak) }\end{array}$ & $\begin{array}{l}\text { - Proses belajar } \\
\text { terjadi } \\
\text { bila siswa } \\
\text { mampu } \\
\text { mengasimilasi } \\
\text { kan } \\
\text { pengetahuan } \\
\text { yang dia miliki } \\
\text { dengan } \\
\text { pengetahuan } \\
\text { yang baru. } \\
\text { - Proses belajar } \\
\text { melalui tahap- } \\
\text { tahap: } \\
\text { Memperhatika } \\
\text { n stimulus yang } \\
\text { diberikan. } \\
\text { Memahami } \\
\text { makna } \\
\text { stimulus. } \\
\text { Menyimpan } \\
\text { dan } \\
\text { menggunakan } \\
\text { informasi yang } \\
\text { sudah } \\
\text { dipahami. }\end{array}$ \\
\hline
\end{tabular}

Sumber : Piaget dkk dalam Sani(2014, 11), Inovasi Pembelajaran 


\subsection{Penelitian Sebelumnya}

Trans Kasiono, Sudjarwo, Gunawan Sudarwanto (2012), tesis ini mengangkat judul Pengaruh Penggunaan Multimedia, Sumber Belajar Dan Nilai Karakter Terhadap Hasil Belajar Siswa SMP Negeri 30 Bandar Lampung. Metode yang digunakan adalah metode kuantitatif dan Pengumpulan data menggunakan angket dan tes sumber belajar dan nilai karakter terhadap hasil belajar. Hasil penelitian ini menunjukkan pengaruh yang signifikan antara pengguna multimedia, sumber belajar dan nilai karakter terhadap hasil belajar IPS Pengaruh yang signifikan antara pengguna Multimedia dan sumber belajar terhadap nilai karakter

Evi Ayu Candra, Tesis Universitas Negeri Malang dengan judul Pengaruh Media Pembelajaran Multimedia Interaktif Melalui Siklus Belajar Terhadap Motivasi Hasil Belajar, dengan menggunakan Rancangan penelitian Eksperimen semudesain pretest-postest dengan Uji statistic analisis kovarian (Anakova). Hasil penelitian menunjukan Terdapat perbedaan motivasi belajar dan hasil belajar afektif yang tidak signifikan antara siswa yang mendapat Multimedia interaktif melalui siklus belajar dengan siswa yang mendapat pembelajaran secara konvensional.

Vony (2015), Tesis Universitas Sebelas maret Surakarta dengan judul Pengaruh Media Pembelajaran Multimedia Interaktif Terhadap Hasil Belajar Hakikat Geografi Ditinjau Dari Tingkat Motivasi Belajar Geografi Siswa Kelas X Ips SMA N 2 Jayapura Tahun 2014. Metode yang digunakan adalah metode Eksperimen semu dengan mengunakan analisis Varian (Anova) dua jalur. Dengan hasil penelitian menunjukkan Terdapat perbedaan yang sangat signifikan antara siswa yang memiliki motivasi belajar rendah dengan motivasi belajar tinggi terhadap hasil belajar geografis serta Terdapat interval yang signifikan antara pengguna media pembelajaran dan motivasi belajar siswa terhadap hasil belajar siswa.

Mi Aina (2013) Tesis Universitas Jambi, yang berjudul Efektifitas Pemanfaatan Multimedia Interaktif Pembelajaran IPA - Bio Dalam Meningkatkan Motivasi Belajar Siswa Pria Dan Wanita SMP 19 Kota Jambi. Dengan Metode Eksperimen (True Eksperiment Desaign) dengan desaign penelitian Pretest- postest Control Group Desaign dan Analisis data menggunakan Uji normalitasUji homogenitasUji Anova dua jalur. Hasil penelitian yang diperoleh yaitu Terdapat pengaruh pemanfaatan Multimedia Interaktf Pembelajaran IPA-Bio terhadap kemampuan kognitif siswa putra dan putri dan Terdapat interaksi antara Multimedia Interaktif dan motivasi siswa putra putri SMP 19 Kota Jambi.

Mia Aina (2012) Tesis Universitas Jambi dengan judul Pengaruh Pemanfaatan Multimedia Interaktif Pembelajaran IPABiologi Terhadap Motivasi Dan Kemampuan Kognitif Siswa SMP 19 Kota Jambi. Metode penelitian yang digunakan adalah metode Eksperimen (True Eksperimen Desaign) dengan desain penelitian Pretest-postest Control Group Desain. Hasil penelitian menunjukkan 1) Terdapat pengaruh 
penggunaan Multimedia interaktif pembelajaran biologi terhadap kemampuan kognitif siswa, 2) Terdapat pengaruh motivasi terhadap kemampuan kognitif siswa, 3) Pada analisa data menggunakan anova untuk interaksi dua faktor, Tidak terdapat interaksi penggunaan media interaktif dan motivasi terhadap kemampuan kognitif

Hari Prasetya (2014), yang berjudul Peranan Teknologi Multimedia Dalam Meningkatkan Efektifitas Pembelajaran Biologi Siswa Kelas XII IPA SMA AlIshar Pondok Lab. metode yang digunakan kuantitatif true eksperimen. Hasil penelitian menunjukkan bahwa Ada Tanggapan positip dari siswa karna belajar menjadi menyenangkan dan efektf serta terdapat peningkatan pemahaman konsep dan pencapaian nilai ulangan harian sangat baik.

Sadam Husen, Lovy herayanti, Gunawan.Jurnal Pendidikan Fisika dan technology (ISSN, 2407-6902) yang Berjudul Pengaruh Penggunaan Multimedia Interaktif Terhadap Penguasaan Konsep, Dan Ketrampilan Berpikir Kritis Siswa Pada Materi Suhu Dan KalorDi SMA 1 Alas, Tahun ajaran 20132014. Hasil penelitian menunjukkan adanya pengaruh Penggunaan Multimedia Interaktif terhadap penguasaan konsep dan ketrampilan berpikir kritis siswa.

Herlina, jurnal Penelitian komunikasi dan Opini Publik STMIK Handayani Makassar. Yang berjudul Pengaruh Pengunaan Multimedia Interaktif Terhadap Minat Belajar Mahasiswa Pada Stmik Handayani, Makasar. Untuk menguji hipotesis penelitian ini menggunakan Metode Eksperimen Desain dengan Analisa data mengunakan Statistik deskriptip Dan analisa hasil observasi. Hasil penelitian menunjukkan adanya perbedaan yang signifikan antara minat belajar mahasiswa yang di ajar dengan mengunakan Multimedia Interaktif dan minat belajar mahasiswa yang di ajarkan tanpa mengunakan Multimedia interaktif

Umti'ah (201) Tesis Institut Agama Islam Negeri Raden Fatah. Yang berjudul Penerapan Multimedia Pembelajaran Terhadap Peningkatan Hasil Belajar Siswa Mata Pelajaran AlIslam Di Sekolah Menengah Atas Muhammadyah 2 Palembang. Untuk menguji hasil hipotesis dalam penelitian ini maka menggunakan Metode Eksperiment,Tes, Observasi, dan Dokumentasi serta Uji prasyaratnya dengan menggunakan Uji Normalitas dan Uji Homogenitas, yang dilakukan pada siswa sekolah menengah atas muhamaddiah palembang tahun 2012. Dengan hasil penelitian yang menunjukkan Terdapat perbedaan antara hasil belajar siswa dalam menjelaskan materi penggurusan jenazamata pelajaran AL-Islam yang diajarkan dengan Multimedia dan hasil belajar siswa yang tidak diajarkan dengan Multimedia.

Riski Dwi Amelia (2016) Tesis Institut Agama Islam (IAIN) Raden Fatah. Yang berjudul Pengaruh Penggunaan Multimedia Interaktif Terhadap Hasil Belajar Siswa Pada Mata Pelajaran Bahasa Arab Di Kelas X SMA Muhammadyah 6 Palembang. Penelitian Kuantatif dengan menggunakan Angket, Tes, dokumentasi,wawancara,

Observasi. Pada penelitian ini menunjukkan adanya pengaruh penggunaan Multimedia Interaktif 
terhadap minat belajar dan hasil belajar siswa

Saiful (2008) Tesis Institut Agama Islam Negeri(IAIN) Raden Fatah. Dengan judul Kompetensi Mengajar Guru Biologi Dan Pengaruhnya Terhadap Prestasi Belajar Siswa Madrasah Aliyah Negeri Kota Palembang. Pada penelitian ini menggunakan Analisis Deskriptif Kuantitatif Dengan mengunakan rumus Statistik regresi sederhana Analisis kualitatip dengan teknik persentase terhadap jawaban kuisoner. Dan diperoleh hasil penelitian yaitu Ada pengaruh kompetensi mengajar guru biologi menerapkan Multimedia terhadap hasilbelajar siswa dan hasil uji regresi $r=$ 0,725ternyata lebih besar dari harga $r=5 \%(0,532)$ Dan harga $r$ $1 \%$ 0,66 Jadi $\mathrm{r}=5 \%\left\langle\mathrm{r} \_0\right\rangle 1 \%$ $(0,532<0,725>0,661)$ Keduanya sangat signifikan

Muklis(2010) TesisInstitut Agama Islam Negeri (IAIN). Dengan judul Efektifitas Pembelajaran Bahasa Arab Menggunakan Multimedia Di Kelas Xi Madrasa Aliyah Swasta Raudhatul Ulum Sakatiga Indralaya Ogan Ilir. Untuk menguji hipotesis pada penelitian ini menggunakan Teknik Analisa Kuntitatif dan deskriptif kualitatif serta Metode penelitian berupa Tes, observasi, dokumentasi. Hasil penelitian ini menunjukkan terdapat perbedaan hasil belajar yang signifikan antara kelompok yang mengunakan Multimedia dengan kelompok yang tanpa mengunakan Multimedia dan tidak terdapat perbedaan hasil belajar yang signifikan antara kelompok yang menggunakan Multimedia dengan klompok yang tanpa Multimedia.
Galuh Kartikasai, jurnal dinamika penelitian, vol.16, no.1, juli 2016, Sekolah tinggi agama islam Miftahul Ula Kertasono. Yang berjudul Pengaruh Media Pembelajaran Berbasis Multimedia Terhadap Motivasi Dan Hasil Belajar Materi Sistem Pencernaan Manusia. Analisis dalam penelitian ini menggunakan kelas eksperiment (true eksperiment desain) dengan desain penelitian pre-test post-test control grup desian. Hasil penelitian ini menyatakan bahwa Nilai rata - rata untuk kelas eksperiment diperoleh nilai tertinggi 63 (pre-test) dan 86,16 (post-test), sedangkan kelas kontrol didapat nilai 61,52 (pretest) dan 79,30 untuk nilai posttest.

\subsection{Kerangka Pemikiran}

Logika berpikir yang digunakan dalam penelitian bahwa penggunaan Multimedia interaktif akan berpengaruh terhadap motivasi begitu juga Multimedia akan berpengaruh terhadap kemampuan kognitif. Multimedia dan motivasi berpengaruh terhadap kemampuan kognitif.

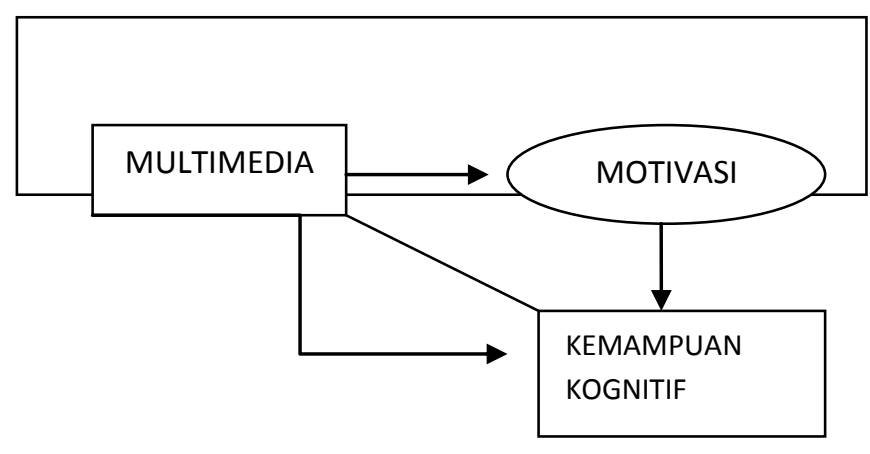

Gambar 2.5 Kerangka Berfikir Gambar 2.6

\subsection{Hipotesis}

1. Ada pengaruh pemanfaatan Multimedia interaktif terhadap motivasi 
2. Ada pengaruh pemanfaatan Multimedia interaktif terhadap kemampuan kognitif siswa.

3. Ada pengaruh pemanfaatan Multimedia interaktif, motivasi terhadap kemampuan kognitif siswa.

\section{METODE PENELITIAN}

\subsection{Metode yang digunakan}

Metode penelitian yang digunakan adalah metode kuantitatif yaitu metode eksperimen (True Eksperiment Design) dengan desain penelitianPretest-Postest control group desaign. Sampel penelitian yang diambil Adalah siswa kelas VII semester genap tahun ajaran 2016-2017 SMPNegeri 14 Kota Palembang.

\subsection{Batasan penelitian}

Populasi penelitian adalah semua siswa kelas VII SMPNegeri 14 Palembang pada semester genap tahun ajaran 2016-2017, yang berjumlah 363 siswa. Pemilihan sampel populasi penelitian diambil empat kelas (130 siswa) yang kondisi prestasi belajar yang hampir sama yaitu $\mathrm{VII}_{8}, \mathrm{VII}_{9}, \mathrm{VII}_{10}, \mathrm{VII}_{11}$ sehingga data yang digunakan sebagai sampel menjadi representatif. Siswa kelas $\mathrm{VII}_{8}, \mathrm{VII}_{9}$, sebagai kelompok perlakuan dan siswa kelas $\mathrm{VII}_{10}, \mathrm{VII}_{11}$ sebagai kelompok kontrol atas dasar penunjukan (purposivee Sampling) Variabel bebas penelitian adalah pembelajaran biologi menggunakan Multimedia interaktif dan pembelajaran konvensional, sedangkan variabel terikat adalah motivasi dan kemampuan kognitif siswa,variabel control meliputi guru, jumlah jam pelajaran, sarana dan prasarana, serta kurikulum yang sama. Pendekatan yang digunakan dalam penelitian adalah pendekatan kuantitatif.

Dapat dilihat dari sumber data yang diperoleh. Sumber data diperoleh dikelompokkan menjadi dua yaitu sumber primer dan sumber sekunder.Sumber yang dimaksud disini adalah data yang diperoleh atau dikumpulkan oleh peneliti secara langsung dari sumber data utama.Sumber primer dalam penelitian ini adalah data motivasi siswa dan nilai siswa. Adapun sumber data sekunder yang dimaksud disini adalah sumber data yang tidak langsung memberikan data kepada peneliti.Sumber sekunder dari penelitian ini yaitu data jumlah siswa dan data jumlah guru di SMP 14 Palembang.

Teknik penggumpulan data yang digunakan dalam penelitian ini meliputi:

1. Teknik angket (kuesioner) Kuesioner merupakan teknik pengumpulan data yang dilakukan dengan memberi seperangkat pertanyaan pernyataan terbuka atau tertutup, dapat diberikan kepada responden secara langsung atau dikirim melalui pos atau internet. Pada penelitian ini metode angket digunakan untuk mengumpulkan data mengenai motivasi belajar. Data motivasi belajar didapat dari angket yangterdiri dari 35 soal menggunakan skala Linkert. Terdiri dari 25 pertanyaan positif dan 10 soal pertanyaan negatif dengan lima pilihan jawaban. Adapun prosedur pemberian skor untuk pertanyaan positif diberi urutan dari sangat setuju (SS), Setuju (ST), Ragu-ragu (RR), Tidak Setuju (TS). Sangat Tidak Setuju (STS), dengan bobot 5,4,3,2, dan 1 sedangkan untuk pernyataan negative diberi bobot skor sebaliknya yaitu 1,2,3,4 dan 5

2. Tes adalah serentetan pertanyaan atau latihan serta alat yang digunakan untuk mengukur keterampilan, pengetahuan intelegensi, kemampuan atau bakat yang dimiliki oleh individu atau kelompok Arikunto $(2006,150)$. Dalam menggunakan teknik tes, tes hasil belajar adalah intrumen yang digunakan dalam penilaian kemampuan kognitif yaitu dengan cara melakukan pre tes dan pos tes yang terdiri dari 20 butirsoal,Setiap butir soal yang dijawab benar diberi skor 5, dan yang salah di beri skor 0 . Tes yang dikembangkan untuk 
menjaring data hasil kemampuan kognitif dibuat dalam bentuk pilihan ganda (multiple choice) dengan empat option yaitu a,b,c,d.

3. Dokumentasi

Arikunto,Suharsimi (2006 ) menyatakan bahwa dokumentasi berasal dari kata dokumen, yang artinya barang - barang tertulis. Dalam penelitian ini dokumentasi digunakan untuk mengumpulkan data seperti jumlah siswa, guru, pegawai dan hal-hal yang berhubungan dengan penelitian. Data ini didapat dari dokumentasi sekolah

4. Observasi

Menurut Sugiyono, observasi merupakan suatu proses yang kompleks, suatu proses yang tersusun dari berbagai proses biologis dan psikologis (Sugiyono, 2013:203). Teknik pengumpulan data dengan observasi digunakan bila peneliti berkenan dengan perilaku manusia, proses kerja, gejala-gejala alam dan bila responden yang diamati tidak terlalu besar.

Observasi dilakukan selama proses pembelajaran dengan menggunakan lembar observasi proses aktivitas pembelajaran siswa menggunakan Multimedia interaktif. Penelitian dibantu observer yang berfungsi mengamati aktivitas peserta didik selama proses pembelajaran berlangsung. Adapun observasi yang digunakan dalam penelitian ini untuk mengetahui keadaan objek secara langsung serta keadaan wilayah, keadaan sarana dan prasarana serta proses pembelajaran dengan Multimedia interaktif di SMP N 14 Palembang.

Instrumen yang digunakan dalam penelitian terdiri dari instrumen variabel bebas dan instrumen variabel terikat.

A. Instrumen variabel bebas antara lain

1. Lembar Observasi, digunakan untuk penilaian apakah pembelajaran telah sesuai dengan sintaks pembelajaran berbasis Multimedia interaktif. Keterlaksanaan pembelajaran yang diamati meliputi kegiatan guru dan kegiatan siswa selama proses pembelajaran serta motivasi siswa dalam mengikuti pembelajaran

B. Instrumen variabel terikat antara lain

1. Angket motivasi belajar siswa adalah instrumen yang digunakan dalam melakukan penilaian motivasi siswa sebelum dilakukan perlakuan dan sesudah diberi perlakuan. Data motivasi belajar didapat dari angket yang terdiri dari 35 soal menggunakan skala Linkert.

Tabel 3.1

Kriteria Penilaian Motivasi

\begin{tabular}{|c|c|}
\hline Motivasi Kuat & $67 \%-100 \%$ \\
\hline Motivasi Sedang & $34 \%-66 \%$ \\
\hline Motivasi Redah & $0 \%-33 \%$ \\
\hline
\end{tabular}

Sumber:Notoatuodjo Soekidjo, 2010

2. Tes hasil belajar adalah instrumen yang digunakan dalam penilaian kemampuan kognitif yaitu dengan cara melakukan pre tes dan post tes yang terdiri dari 20 soal yang sudah divalidasi.

Tabel 3.2

Kriteria Penilaian HasilBelajar

\begin{tabular}{|c|c|c|}
\hline Kriteria & Kategori & Keterangan \\
\hline A & $\begin{array}{c}\text { Sangat } \\
\text { Baik }\end{array}$ & $86-100$ \\
\hline B & Baik & $71-85$ \\
\hline $\mathrm{C}$ & Cukup & $56-70$ \\
\hline $\mathrm{D}$ & Kurang & $<-55$ \\
\hline
\end{tabular}

Tabel 3.3

Tabel Kemampuan Kognitif

\begin{tabular}{|c|c|c|c|}
\hline & Indikator & $\begin{array}{c}\text { Nomor } \\
\text { Soal }\end{array}$ & $\begin{array}{c}\text { Jumlah } \\
\text { Soal }\end{array}$ \\
\hline $\begin{array}{c}\text { Kemampuan } \\
\text { Kognitif } \\
\text { 1.Ingatan/ } \\
\text { Recall (C1) } \\
\text { 2. Pemahaman/ } \\
\text { Comprehensi } \\
\text { (C2) }\end{array}$ & $6,19,20$ & 3 \\
3.Aplikasi/ & $9,2,5,8,12$ & 6 \\
\hline
\end{tabular}




\begin{tabular}{|l|l|c|c|}
\hline & $\begin{array}{l}\text { Penarapan } \\
\text { (C3) }\end{array}$ & 17,18 & 3 \\
$\begin{array}{l}\text { 4. Analisis/ } \\
\text { Analys (C4) }\end{array}$ & $11,14,15$ & 3,7 & 2 \\
$\begin{array}{l}\text { 5. Sintesis (C5) } \\
\text { 6. Evaluasi/ } \\
\text { Evaluasion } \\
\text { (C6) }\end{array}$ & 13 & 1 \\
\hline
\end{tabular}

3. Prosedur pengembangan skala Likert mengacu pada respon yang diberikan siswa mencakup aspek kognisi, afeksi, dan kohasi dengan tingkat kesetujuan yang berbeda, yaitu sangat setuju (SS), setuju (ST), ragu - ragu (RR), tidak setuju (TS), dan sangat tidak setuju (STS). Pemberian skor unuk pertanyataan positif diberi urutan dari SS, ST, TS, dan SS dengan bobot skor 5, 4, 3, 2 dan 1 sedangkan untuk pernyatan negatif diberikan bobot skor sebaliknya yaitu $1,2,3,4$, dan 5 . Instrumen penelitian ini dijelaskan pada tabel 3.1

Tabel 3.4

Tabel Motivasi Belajar

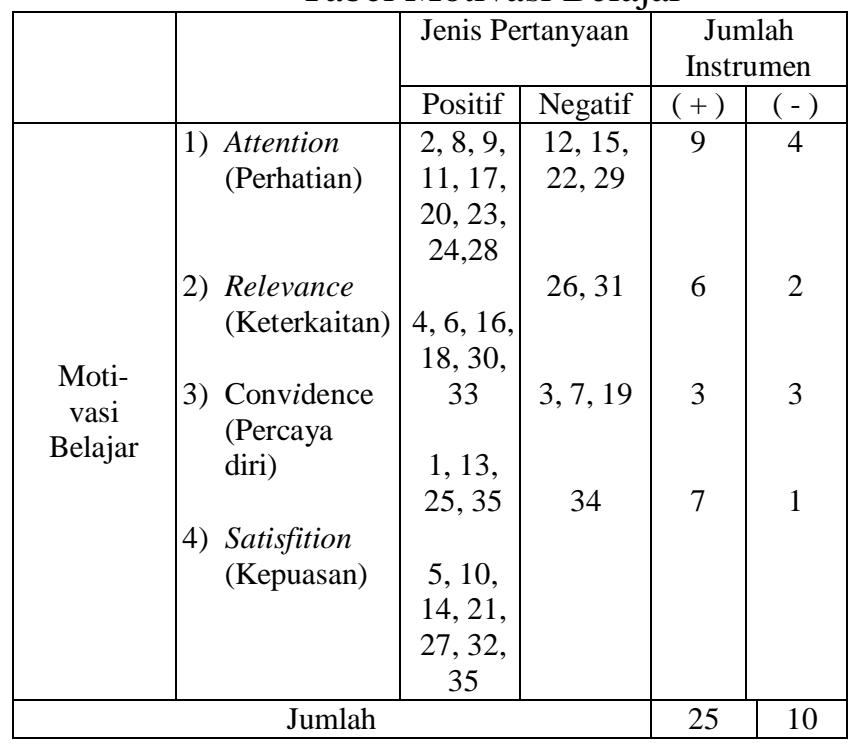

Tabel 3.5 Instrumen Penelitian

\begin{tabular}{|c|l|l|l|}
\hline No & \multicolumn{1}{|c|}{ Variabel } & \multicolumn{1}{c|}{ Instrumen } & $\begin{array}{c}\text { Teknis } \\
\text { Pengumpulan } \\
\text { Data }\end{array}$ \\
\hline 1 & $\begin{array}{l}\text { Pembelajaran } \\
\text { dengan } \\
\text { Multimedia } \\
\text { interaktif }\end{array}$ & $\begin{array}{l}\text { - Lembar observasi } \\
\text { keterlaksanaan } \\
\text { pembelajaran oleh } \\
\text { guru }\end{array}$ & Observasi \\
& & $\begin{array}{l}\text { Lembar observasi } \\
\text { ketelaksanaan } \\
\text { pembelajaran oleh } \\
\text { siswa } \\
\text { Catatan lapangan }\end{array}$ & Observasi \\
& & Observasi \\
\hline 2 & Motivasi belajar & & \\
\hline
\end{tabular}

\begin{tabular}{|c|c|c|c|}
\hline & \begin{tabular}{ll}
\multicolumn{2}{l}{$\begin{array}{l}\text { siswa } \\
\text { a. }\end{array}$} \\
$\begin{array}{l}\text { Attention } \\
\text { (perhatian } \\
\text { terhadap } \\
\text { pelajaran) }\end{array}$ \\
b. $\begin{array}{l}\text { Relevance } \\
\text { (keterkaitan) }\end{array}$ \\
c. $\begin{array}{l}\text { Confidence } \\
\text { (keyakinan }\end{array}$ \\
& $\begin{array}{l}\text { diri/ percaya } \\
\text { diri) }\end{array}$ \\
d. & $\begin{array}{l}\text { Satisfition } \\
\text { (kepuasan) }\end{array}$ \\
\end{tabular} & $\begin{array}{l}\text { Angket motivasi } \\
\text { belajar siswa } \\
\text { Angket motivasi } \\
\text { belajar siswa }\end{array}$ & $\begin{array}{l}\text { Observasi } \\
\text { Observasi } \\
\text { Observasi }\end{array}$ \\
\hline 3 & $\begin{array}{l}\text { Hasil Belajar } \\
\text { siswa } \\
\bullet \quad \text { Kognitif }\end{array}$ & $\begin{array}{l}\text { Tes hasil belajar } \\
\text { kognitif }\end{array}$ & $\begin{array}{l}\text { Tes hasil } \\
\text { belajar } \\
\text { kognitif }\end{array}$ \\
\hline
\end{tabular}

\subsection{Rancangan Analisa Data}

Analisa data dengan statistic deskriptif untuk menggambarkan hasil penelitian secara umumdan statistic parametric untuk menguji hipotesis dilakukan dengan menggunakan analisa Uji t. Uji t digunakan untuk mengetahui pengaruh penggunaan multimedia interaktif terhadap motivasi dan kemampuan kognitif.Uji anakova untuk mengetahui perbedaan motivasi dan kemampuan kognitif siswa antara kelas eksperimen dengan kelas control. Sebelum dilakukan Uji t terlebih dahulu dilakukan uji prasyarat yaitu uji normalitas dan uji homogenitas. Uji statistic pada penelitian ini menggunakan SPSS.22 Observasi juga dilakukan selama kegiatan pembelajaranguna mengetahui keterlaksanaan pembelajaran oleh guru dan pembelajaran yang di alami siswa berdasarkan descriptor yang telah direncanakan. Pencatatan data selama observasi dibantu oleh observer dengan menggunakan intrumen berupa lembar keterlaksanaan pembelajaran oleh guru dan siswa yang telah disusun sebelum pelaksanaan penelitian.

\subsection{Rancangan Pengujian Hipotesis}

1. Uji Prasyarat Analisis

a. Uji normalitas

Menurut Sugiyono (2007: 79), uji normalitas bertujuan untuk mengetahui apakah data yang terkumpul berdistribusi normal atau tidak. Dengan uji normalitas akan diketahui sampel yang diambil berasal dari populasi yang berdistribusi normal atau tidak. Apabila pengujian 
normal, maka hasil perhitungan statistik dapat digeneralisasi pada populasinya. Pedoman untuk melihat kenormalan ini menggunakan uji normalitas dengan uji kolmogorov Smirnov, kriterianya adalah:

1) Jika D (Determinan) hitung > D (Determinan) Pada tabel, maka distribusi data tidak normal. (Dh > D, ) 0,05)

2) Jika $D$ (Determinan) hitung > D (Determinan) Pada tabel, maka distribusi data normal. $(\mathrm{Dh}<\mathrm{D}$, ) 0,05)

3) Pengujian normalitas dalam penelitian ini dilakukan dengan menggunakan Chi Kuadrat $\left(X^{2}\right)$.

Rumus untuk mencari Chi Kuadrat adalah seperti diawah ini :

$$
x^{2}=\sum_{i=1}^{K} \frac{\left(f_{a}-f_{b}\right)^{2}}{f_{b}}
$$

$\mathrm{X}^{2}=$ Chi Kuadrat

$f_{a}=$ Frekuensi yang diobservasi

$f_{b}=$ Frekuensi yang diharapkan

Harga chi kuadrat hitung dibandingkan dengan harga chi kuadrat tabel pada taraf signifikan 5\% dengan derajat kebebasan k$1, \mathrm{k}$ adalah banyak kelas. Apabila harga chi kuadrat hitung lebih kecil dari chi kuadrat table maka data tersebut dapat dinyatakan berdistribusi normal, tetapi sebaliknya apabila harga chi kuadrat hitung lebih besar dari chi kuadat tabel, maka dapat dinyatakan berdistribusi tidak normal.

\section{b. .Uji Homogenitas}

Menurut Sugiyono (2007: 107), uji ini dimaksudkan untuk menguji kesamaan varians populasi yang berdistribusi normal. Uji homogenitas menggunakan uji Barletts. Jika nilai probbalitasnya $>0,05$ maka data berasal dari populasi yang variansnya sama atau homogen berupa varians data $\mathrm{Y}$ berdasarkan kelompok $\mathrm{X}$, Kriterianya adalah:
1) Jika $X$ hitung $>X$ tabel, data tidak homogen

2) Jika $X$ hitung $<X$ tabel, data homogen

Pengujian homogenitas dalam penelitian ini menggunakan uji varians terbesar dibandingkan varians terkecil yang menggunakan tabel $F$ yang rumusnya sebagai berikut:

$$
\mathrm{F}_{\text {hitung }}=\frac{\text { Variansterbesar }}{\text { variansterkecil }}
$$

Harga $\mathrm{F}_{\text {hitung }}$ yang telah

diperoleh dibandingkan dengan $\mathrm{F}_{\text {tabel }}$ pada taraf signifikasi 5\% dengan derajat kebebasan pembilang n-1 dan derajat kebebasan penyebuut $\mathrm{n}$-1. Apabila $\mathrm{F}_{\text {hitung }} \geq \mathrm{F}_{\text {tabel, }}$, maka tidak homogen, tetapi apabila $\mathrm{F}_{\text {hitung }} \leq \mathrm{F}_{\text {tabel, }}$ maka homogen.

\section{Uji Hipotesis}

Setelah uji normalitas dan uji homogenitas dilakukan maka selanjutnya dilakukan uji hipotesis seperti dibawah ini. Uji hipotesis dilakukan dengan uji t. Data yang telah terkumpul berupa skor baik yang berasal dari angket motivasi belajar maupun tes kemampuan kognitif dimasukkan ke dalam tabel yang telah disediakan untuk selanjutnya dianalisis dengan rumusan statisik uji t.

Jadi uji $\mathrm{t}$ digunakan untuk mengetahui pengaruh penggunaan suatu media, yang mana dalam penelitian ini adalah untuk menganalisis data tentang ada tidaknya pengaruh penggunaan Multimedia interaktif terhadap motivasi belajar dan kemampuan kognitif.

Analisis data yang dilakukan yaitu meggunakan rumus " $\mathrm{t}$ " test ( Anas Sudijono, 2010)

$$
t_{0} \frac{M_{1}-M_{2}}{S E_{M_{1}-M_{2}}}
$$

Langkah perhitungannya:

a. Mencari mean variabel $\mathrm{X}$ (Variabel 1), dengan rumus:

$$
M_{1}=M^{\prime}+i\left(\frac{\sum f x^{\prime}}{N_{1}}\right)
$$


b. Mencari mean variabel $\mathrm{Y}$ (Variabel II), dengan rumus:

$$
M_{2}=M^{\prime}+i\left(\frac{\sum f y^{\prime}}{N_{2}}\right)
$$

c. Mencari deviasi standar variabel I dengan rumus:

$$
S D_{1}=i \sqrt{\frac{\sum f x^{\prime 2}}{N_{1}}}-\left(\frac{\sum f x^{\prime}}{N_{1}}\right)^{2}
$$

d. Mencari deviasi sandar variabel II dengan rumus:

$$
S D_{1}=i \sqrt{\frac{\sum f{y^{\prime}}^{2}}{N_{2}}}-\left(\frac{\sum f y^{\prime}}{N_{2}}\right)^{2}
$$

e. Mencari standarr error mean variabel I dengan rumus:

$$
S E_{M_{1}}=\frac{S D_{1}}{\sqrt{N_{1}-1}}
$$

f. Mencari standarr error mean variabel II dengan rumus:

$$
S E_{M_{2}}=\frac{S D_{2}}{\sqrt{N_{2}-1}}
$$

g. Mencari sandard error perbedaan mean variabel I dan mean variabel II dengan rumus:

$$
S E_{M_{1}-M_{2}}=\sqrt{S E_{M_{1}}^{2}}+S E_{M_{2}}^{2}
$$

h. Mencari $t_{0}$ dengan rumus:

$$
t_{0} \frac{M_{1}-M_{2}}{S E_{M_{1}-M_{2}}}
$$

Untuk menguji hipotesis digunakan rumus " $t$ " test atau uji t. Apabila $t_{\text {hitung }}\left(t_{0}\right)$ lebih besar dari $t_{\text {tabel }}\left(t_{t}\right)$ maka hipotesis alternatif diterima dan hipotesis nihil ditolak. Begitu pula sebaliknya apabila $t_{0}$ lebih kecil dari $t_{t}$ maka hipotesis nihil dan hipotesis alernatif ditolak.

Pengujian hipotesis ini menggunakan uji $\mathrm{t}$ dengan derajat kebebasan $(\mathrm{db})=\left(N_{1}+\right.$ $N_{2}-2$ ), pada taraf signifikan $5 \%$. Kriteria pengujian hipotesis dengan menggunakan uji t. Pada $\alpha=0,05$ dan $d f$ (Degrees of Freedom) $\mathrm{N}_{1}+\mathrm{N}_{2}$

\section{Hipotesis Statistik}

Untuk menguji hipotesis, maka hipotesis penelitian diubah menjadi hipotesis statistik yaitu $\mathrm{H}_{0}$ dan $\mathrm{H}_{a}$ yang dapat dinotasikan sebagai berikut:

a. $\mathrm{H}_{0}: \mu_{1}-\mu_{1} \leq 0$

Tidak terdapat pengaruh penggunaan Multimedia interaktif terhadap motivasi belajar siswa pada mata pelajaran IPA-Biologi kelas VII SMP Negeri 14 Palembang

$$
\mathrm{H}_{a}: \mu_{1}-\mu_{1}>0
$$

Terdapat pengaruh penggunaan Multimedia interaktif terhadap motivasi belajar siswa pada mata pelajaran IPA-Biologi kelas VII SMP Negeri 14 Palembang.

b. $\mathrm{H}_{0}: \mu_{3}-\mu_{4} \leq 0$

Tidak terdapat pengaruh penggunaan Multimedia interaktif terhadap kemampuan kognitif pada mata pelajaran IPA-Biologi kelas VII SMPNegeri 14 Palembang

$$
\mathrm{H}_{a}: \mu_{3}-\mu_{4}>0
$$

Terdapat pengaruh penggunaan Multimedia interaktif terhadap hasil kemampuan kognitif pada mata pelajaran IPA-Biologi kelas VII SMP Negeri 14 Palembang.

\section{ANALISIS DAN PEMBAHASAN \\ 4.1 Hasil Penelitian}

Sebelum instrumen diberikan kepada kelas yang diteliti, terlebih dahulu diujicobakan pada kelas ujicoba agar diperoleh butir soal yang masuk ketagori baik dan bisa digunakan untuk penelitian.

\section{Deskripsi Data Hasil Penelitian}
a. Keterlaksanaan
Pembelajaran
Menggunakan Multimedia interaktif.
Keterlaksanaan pembelajaran oleh guru dan siswa dapat diketahui dari lembar pengamatan keterlaksanaan pembelajaran oleh guru dan siswa yang didalamnya berisi perolehan deskriptor yang muncul selama pembelajaran. Data keterlaksanaan pembelajaran oleh guru dan siswa selengkapnya dapat dilihat pada tabel 4.6 berikut. 
Tabel 4.6

Keterlaksananan Pembelajaran Oleh Guru dan Siswa

\begin{tabular}{|c|c|c|c|}
\hline $\begin{array}{c}\text { Pembelajar } \\
\text { an }\end{array}$ & $\begin{array}{c}\text { Deskriptor } \\
\text { yang } \\
\text { muncul }\end{array}$ & $\begin{array}{c}\text { Total } \\
\text { Deskriptor }\end{array}$ & $\begin{array}{c}\text { Keterlak } \\
\text { sanaan } \\
\text { Pembela } \\
\text { jaran } \\
(\%)\end{array}$ \\
\hline Oleh Guru & 12 & 12 & 100 \\
\hline Oleh Siswa & 12 & 12 & 100 \\
\hline Rata-rata & 12 & 12 & 100 \\
\hline
\end{tabular}

Tabel 4.7

Rata-rata Nilai Motivasi Siswa Pada Kelas Eksperimen dan Kelas Kontrol

\begin{tabular}{|c|l|c|c|c|c|c|}
\hline $\begin{array}{c}\mathrm{N} \\
\mathrm{o}\end{array}$ & Kelas & $\begin{array}{c}\text { Rata- } \\
\text { rata } \\
\text { Nilai Pre } \\
\text { Tes }\end{array}$ & $\begin{array}{c}\text { Kate } \\
\text { gori }\end{array}$ & $\begin{array}{c}\text { Rata- } \\
\text { rata } \\
\text { Nilai } \\
\text { Post tes }\end{array}$ & $\begin{array}{c}\text { Kate } \\
\text { gori }\end{array}$ & $\begin{array}{c}\text { Persen } \\
\text { tase } \\
\text { Pening } \\
\text { katan }\end{array}$ \\
\hline 1 & $\begin{array}{l}\text { Eksperi } \\
\text { men }\end{array}$ & 77,99 & Baik & 85,40 & Baik & $7,22 \%$ \\
\hline 2 & Kontrol & 77,93 & Baik & 82,88 & Baik & $5,03 \%$ \\
\hline
\end{tabular}

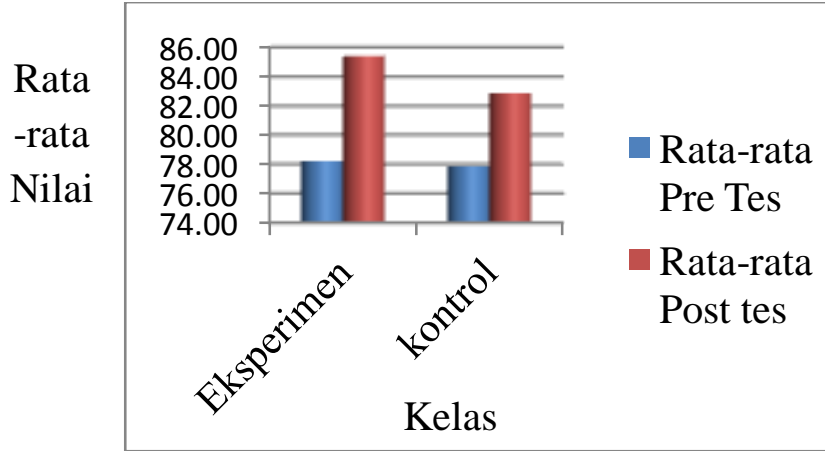

Gambar 4.1

HistogramRata-rata Nilai Motivasi Siswa Pada Kelas Eksperimen dan Kelas Kontrol

Berdasarkan pada setiap aspek motivasi yaitu attention (A), Relevance (R), Confidence (C), dan Satisfaction (S), maka didapatkan rata-rata nilai setiap aspek motivasi tertera pada Tabel 4.8 dan Tabel 4.9 berikut

\section{Tabel 4.8}

Rata-rata Nilai Setiap Aspek Motivasi Pada Kelas Eksperimen

\begin{tabular}{|c|c|c|c|c|c|c|}
\hline $\begin{array}{l}N \\
\mathrm{o}\end{array}$ & $\begin{array}{c}\text { Aspek } \\
\text { Motivasi }\end{array}$ & $\begin{array}{c}\text { Rata- } \\
\text { rata } \\
\text { Nilai } \\
\text { Pre } \\
\text { Tes }\end{array}$ & $\begin{array}{l}\text { Kate } \\
\text { gori }\end{array}$ & $\begin{array}{l}\text { Rata- } \\
\text { rata } \\
\text { Nilai } \\
\text { Post } \\
\text { tes }\end{array}$ & $\begin{array}{c}\text { Kate } \\
\text { gori }\end{array}$ & $\begin{array}{c}\text { Persenta } \\
\text { se } \\
\text { Pening- } \\
\text { katan }\end{array}$ \\
\hline
\end{tabular}

\begin{tabular}{|c|c|c|c|c|c|c|}
\hline 1 & Attention & 77,45 & Baik & 84,02 & Baik & $6,57 \%$ \\
\hline 2 & Relevance & 76,25 & Baik & 84,21 & Baik & $7,96 \%$ \\
\hline 3 & Confidence & 72,40 & Baik & 81,22 & Baik & $8,82 \%$ \\
\hline 4 & Satisfaction & 85,66 & Baik & 92,00 & $\begin{array}{c}\text { San } \\
\text { gat } \\
\text { Baik }\end{array}$ & $6,33 \%$ \\
\hline
\end{tabular}

Tabel 4.9

Rata-rata Nilai Setiap Aspek Motivasi Pada Kelas Kontrol

\begin{tabular}{|c|c|c|c|c|c|c|}
\hline No & $\begin{array}{c}\text { Aspek } \\
\text { Motivasi }\end{array}$ & $\begin{array}{c}\text { Rata- } \\
\text { rata } \\
\text { Nilai } \\
\text { Pre Tes }\end{array}$ & $\begin{array}{c}\text { Kate } \\
\text { gori }\end{array}$ & $\begin{array}{c}\text { Rata-rata } \\
\text { Nilai } \\
\text { Post tes }\end{array}$ & $\begin{array}{c}\text { Kate } \\
\text { gori }\end{array}$ & $\begin{array}{c}\text { Persen- } \\
\text { tase } \\
\text { Pening } \\
\text { katan }\end{array}$ \\
\hline 1 & Attention & 77,04 & Baik & 80,39 & Baik & $3,35 \%$ \\
\hline 2 & Relevance & 75,47 & Baik & 82,30 & Baik & $6,83 \%$ \\
\hline 3 & Confidence & 73,70 & Baik & 79,52 & Baik & $5,83 \%$ \\
\hline 4 & Satisfaction & 84,65 & Baik & 90,01 & $\begin{array}{c}\text { Sang } \\
\text { at } \\
\text { Baik }\end{array}$ & $5,37 \%$ \\
\hline
\end{tabular}

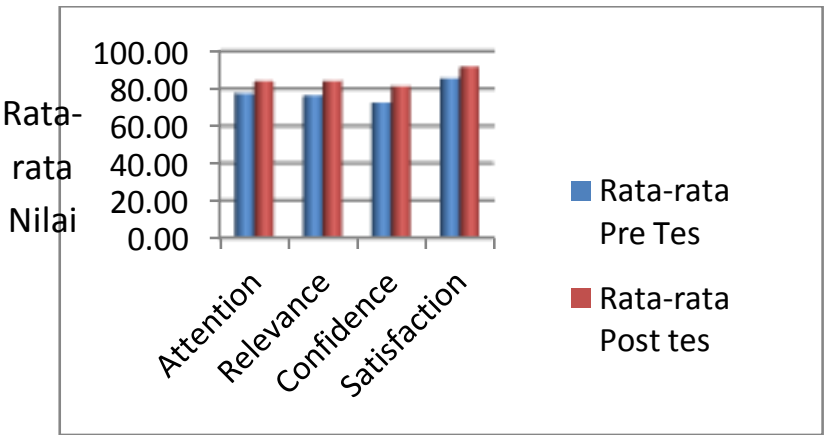

Aspek Motivasi

Gambar 4.2

Histogram Rata-rata Nilai Setiap Aspek motivasi pada Kelas Eksperimen

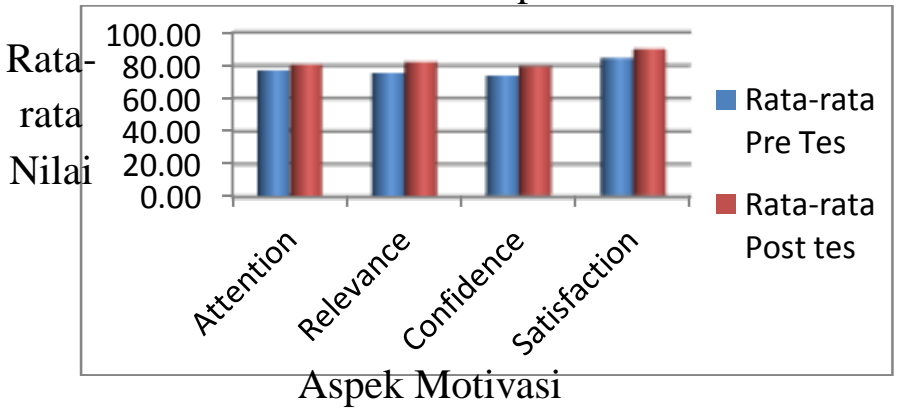

Gambar 4.3

Histogram Rata-rata Nilai Setiap Aspek motivasi pada Kelas Kontrol 
b. Hasil Belajar kognitif Kelas VII SMP Negeri 14 Palembang

Tabel 4.10

Rata-rata Nilai Hasil belajar Kognitif pada Kelas Eksperimen dan Kelas

Kontrol

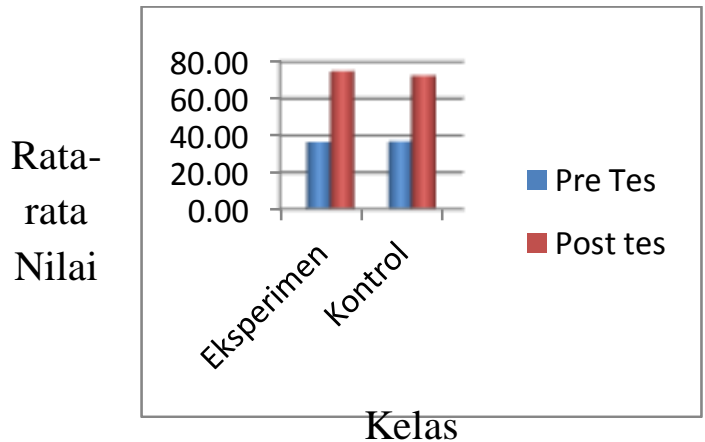

Gambar 4.4

Histogram Rata-rata Nilai Motivasi Belajar Siswa pada Kelas Eksperimen dan Kelas Kontrol

Berdasarkan pada setiap aspek hasil belajar kognitif yaitu $\mathrm{C} 1, \mathrm{C} 2, \mathrm{C} 3$, $\mathrm{C} 4, \mathrm{C} 5$ dan $\mathrm{C} 6$, maka didapatkan ratarata nilai setiap aspek hasil belajar kognitif tertera pada Tabel 4.11 dan Tabel 4.12

Tabel 4.11

Rata-rata Nilai Setiap Aspek Hasil belajar Kognitif pada Kelas Eksperimen

\begin{tabular}{|c|c|c|c|c|c|c|}
\hline $\begin{array}{c}\mathrm{N} \\
\mathrm{o}\end{array}$ & $\begin{array}{c}\text { Aspek } \\
\text { Kognitif }\end{array}$ & $\begin{array}{c}\text { Rata- } \\
\text { rata } \\
\text { Nilai } \\
\text { Pre Tes }\end{array}$ & $\begin{array}{c}\text { Kate } \\
\text { gori }\end{array}$ & $\begin{array}{c}\text { Rata- } \\
\text { rata } \\
\text { Nilai } \\
\text { Post } \\
\text { tes }\end{array}$ & $\begin{array}{c}\text { Kate } \\
\text { gori }\end{array}$ & $\begin{array}{c}\text { Persen- } \\
\text { tase } \\
\text { Pening } \\
\text { katan }\end{array}$ \\
\hline 1 & $\mathrm{C} 1$ & 15,91 & $\begin{array}{c}\text { Kura } \\
\text { ng }\end{array}$ & 75,00 & Baik & $59,09 \%$ \\
\hline 2 & $\mathrm{C} 2$ & 34,63 & $\begin{array}{c}\text { Kura } \\
\text { ng }\end{array}$ & 74,68 & Baik & $40,04 \%$ \\
\hline 3 & $\mathrm{C} 3$ & 37,23 & $\begin{array}{c}\text { Kura } \\
\text { ng }\end{array}$ & 73,81 & Baik & $36,58 \%$ \\
\hline 4 & $\mathrm{C} 4$ & 55,30 & $\begin{array}{c}\text { Kura } \\
\text { ng }\end{array}$ & 71,21 & Baik & $15,91 \%$ \\
\hline 5 & C5 & 43,94 & $\begin{array}{c}\text { Kura } \\
\text { ng }\end{array}$ & 96,97 & $\begin{array}{c}\text { Sang } \\
\text { at } \\
\text { Baik }\end{array}$ & $53,03 \%$ \\
\hline 6 & C6 & 36,36 & $\begin{array}{c}\text { Kura } \\
\text { ng }\end{array}$ & 69,70 & $\begin{array}{c}\text { Cuku } \\
\text { p }\end{array}$ & $33,33 \%$ \\
\hline
\end{tabular}

Tabel 4.12 Rata-rata Nilai Setiap Aspek Hasil belajar Kognitif pada Kelas Kontrol

\begin{tabular}{|c|c|c|c|c|c|c|}
\hline No & Kelas & $\begin{array}{c}\text { Rata- } \\
\text { Nata } \\
\text { Nilai } \\
\text { Tes }\end{array}$ & $\begin{array}{c}\text { Kate } \\
\text { gori }\end{array}$ & $\begin{array}{c}\text { Rata- } \\
\text { rata } \\
\text { Nilai } \\
\text { Post } \\
\text { tes }\end{array}$ & $\begin{array}{c}\text { Kate } \\
\text { gori }\end{array}$ & $\begin{array}{c}\text { Perse } \\
\text { ntase } \\
\text { Penin } \\
\text { gkata } \\
\text { n }\end{array}$ \\
\hline 1 & $\begin{array}{c}\text { Eksperi } \\
\text { men }\end{array}$ & 36,29 & Kurang & 74,92 & Baik & $\begin{array}{c}38,64 \\
\%\end{array}$ \\
\hline 2 & Kontrol & 36,97 & Kurang & 72,46 & Baik & $\begin{array}{c}35,49 \\
\%\end{array}$ \\
\hline $\begin{array}{c}\text { N } \\
\text { o }\end{array}$ & $\begin{array}{c}\text { Aspek } \\
\text { Kog- } \\
\text { nitif }\end{array}$ & $\begin{array}{c}\text { Rata- } \\
\text { rata } \\
\text { Nilai }\end{array}$ & $\begin{array}{c}\text { Kate } \\
\text { gori }\end{array}$ & $\begin{array}{c}\text { Rata- } \\
\text { Nata } \\
\text { Post } \\
\text { tes }\end{array}$ & $\begin{array}{c}\text { Kate } \\
\text { gori }\end{array}$ & $\begin{array}{c}\text { Persen- } \\
\text { tase } \\
\text { Pening } \\
\text { katan }\end{array}$ \\
\hline 1 & C1 & 23,77 & $\begin{array}{c}\text { Kura } \\
\text { ng }\end{array}$ & 73,77 & Baik & $\begin{array}{c}50,00 \\
\%\end{array}$ \\
\hline 2 & C2 & 35,36 & $\begin{array}{c}\text { Kura } \\
\text { ng }\end{array}$ & 71,90 & Baik & $\begin{array}{c}36,53 \\
\%\end{array}$ \\
\hline 3 & C3 & 35,13 & $\begin{array}{c}\text { Kura } \\
\text { ng }\end{array}$ & 72,37 & Baik & $\begin{array}{c}37,24 \\
\%\end{array}$ \\
\hline 4 & C4 & 53,28 & $\begin{array}{c}\text { Kura } \\
\text { ng }\end{array}$ & 74,59 & Baik & $\begin{array}{c}21,31 \\
\%\end{array}$ \\
\hline 5 & C5 & 49,18 & $\begin{array}{c}\text { Kura } \\
\text { ng }\end{array}$ & 72,13 & Baik & $\begin{array}{c}22,95 \\
\%\end{array}$ \\
\hline 6 & C6 & 42,62 & $\begin{array}{c}\text { Kura } \\
\text { ng }\end{array}$ & 70,49 & $\begin{array}{c}\text { Cuku } \\
\text { p }\end{array}$ & $\begin{array}{c}27,87 \\
\%\end{array}$ \\
\hline
\end{tabular}

Ratarata Nilai

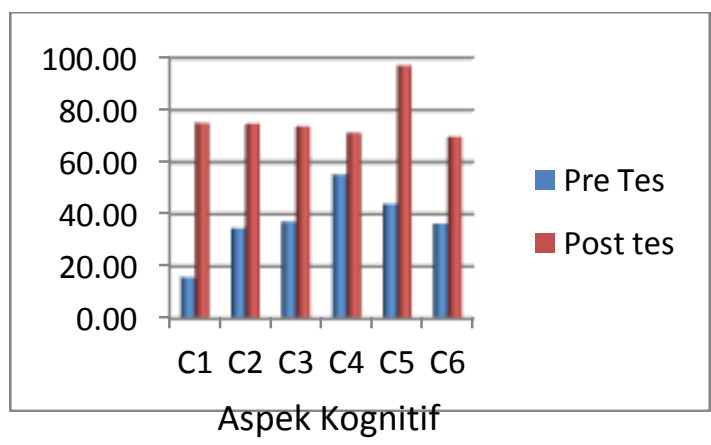

Gambar 4.5

Histogram Rata-rata Nilai Setiap Aspek Hasil Belajar Kognitif Pada Kelas Eksperimen 


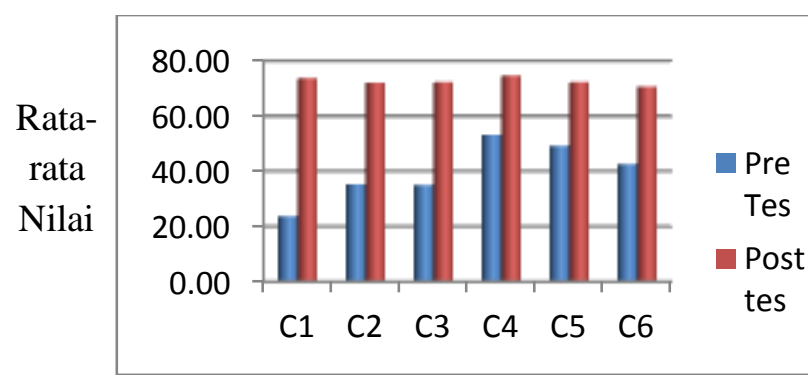

Aspek Kognitif

Gambar 4.6

Histogram Rata-rata Nilai Setiap

Aspek Hasil Belajar Kognitif Pada

Kelas Kontrol

\subsection{Analisis dan Pembahasan}

\subsubsection{Analisis Data Hasil Penelitian Secara Statistik}

A. Uji Prasyarat Analisis

1. Uji Normalitas Data

Uji normalitas data pada penelitian ini dilakukan dengan Uji

Kolmogorov-Smirnov. Data

Penelitian dikatakan terdistribusi normal jika jika nilai taraf signifikasi lebih dari 0,025. Taraf signifikasi hasil uji normalitas pada motivasi awal berdasarkan hasil pre tes sebesar 0,439>0,025. Sedangkan untuk taraf signifikasi hasil uji normalitas pada motivasi akhir berdasarkan hasil pos tes sebesar $0,471>0,025$. Taraf signifikasi hasil uji normalitas pada hasil belajar kognitif awal berdasarkan hasil pre tes sebesar $0,098>0,025$. Sedangkan untuk taraf signifikasi hasil uji normalitas pada hasil belajar kognitif akhir berdasarkan hasil post tes sebesar $0,337>0,025$. Berdasarkan data tersebut dapat dikatakan bahwa data terdistribusi normal

2. Uji Homogenitas data

Uji homogenitas data pada penelitian ini dilakukan dengan Uji Levene's. Data dikatakan homogen jika taraf signifikansi lebih dari 0,05. Taraf signifikansi pada motivasi awal berdasarkan hasil pretes sebesar $0,980>0,05$. Sedangkan taraf signifikansi pada motivasi akhir berdasarkan hasil post tes sebesar 0,124>0,05. Taraf signifikansi pada hasil belajar kognitif awal berdasarkan hasil pre tes sebesar $0,098>0,05$. Sedangkan untuk taraf signifikansi hasil belajar kognitif akhir berdasarkan hasil post tes sebesar $0,989>0,05$. Berdasarkan data tersebut dapat disimpulkan bahwa data dikatakan homogen.

\subsubsection{Pembahasan}

Tabel 4.13 Regression (Regresi Variabel X1 dan X2 terhadap Y1)

Descriptive Statistics

\begin{tabular}{|c|c|c|c|}
\hline & Mean & Std. Deviation & N \\
\hline Y1 & 3.9371 & .26637 & 65 \\
X1 & 54.9615 & 8.69955 & 65 \\
X2 & 54.7308 & 9.70385 & 65 \\
& & & \\
\hline
\end{tabular}

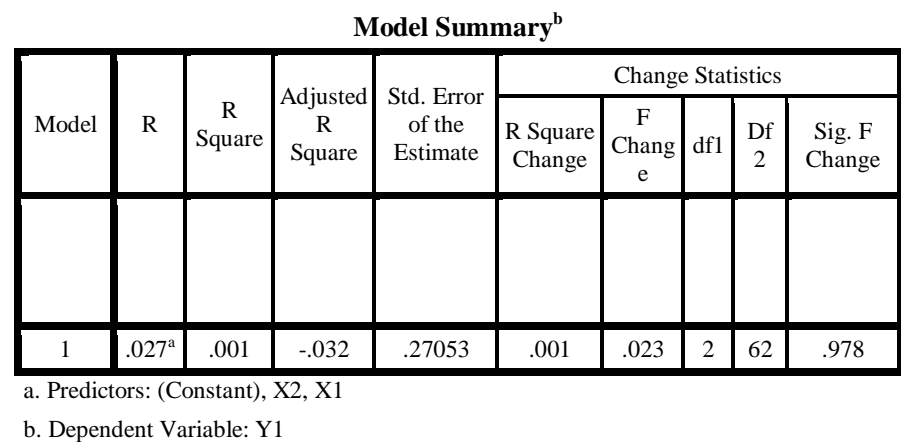

Sumber data primer yang diolah tahun 2017

- Angka R (koefisien korelasi) sebesar 0,027 menunjukkan bahwa korelasi/hubungan antara Y1 dengan variabel independent (X1 dan X2) adalah sebesar $2,7 \%$ adalah tidak kuat, karena nilai $\mathrm{R}<80 \%$

- Angka R Square (koefisien determinasi) adalah 0,001 yang didapat dari pengkuadratan koefisien korelasi atau $0,027 \times 0,027$. Hal ini berarti bahwa $1 \%$ variasi dari Y1 tidak bisa dijelaskan oleh variasi dari variabel X1 dan $\mathrm{X} 2$, sedangkan sisanya sebesar $99 \%$ dijelaskan oleh variabel lain 
ANOVA $^{b}$

\begin{tabular}{|l|c|c|c|c|c|}
\hline Model & Sum of Squares & df & $\begin{array}{c}\text { Mean } \\
\text { Square }\end{array}$ & F & Sig. \\
\hline $\begin{array}{l}\text { Regressi } \\
\text { on }\end{array}$ & .003 & 2 & .002 & .023 & .97 \\
$8^{\mathrm{a}}$ \\
$\begin{array}{l}\text { Residual } \\
\text { Total }\end{array}$ & 4.538 & 62 & .073 & & \\
\hline
\end{tabular}

a. Predictors: (Constant), X2, X1

b. Dependent Variable: Y1

Sumber data primer yang diolah tahun 2017

- Dari Uji ANOVA atau F test, didapat $F$ hitung sebesar 0,023 dengan tingkat signifikan 0,978 karena probabilitas jauh lebih besar dari 0,05 maka model regresi tidak bisa dipakai untuk memprediksi Y1 atau bisa dikatakan bahwa X1 dan X2 tidak berpengaruh terhadap Y1

- .Uji t untuk menguji signifikansi konstanta dan setiap variabel independent. Hipotesis :

$\mathrm{HO}=$ Koefisien regresi tidak signifikan

$\mathrm{H} 1$ = Koefisien regresi signifikan

- Variabel X1 dan X2 mempunyai angka signifikan diatas 0,05 . Oleh karena itu, variabel tersebut tidak berpengaruh (tidak signifikan secara statistik) terhadap Y1

\section{Coefficients}

\begin{tabular}{|c|c|c|c|c|c|}
\hline \multirow{2}{*}{ Model } & \multicolumn{2}{|c|}{$\begin{array}{l}\text { Unstandardized } \\
\text { Coefficients }\end{array}$} & $\begin{array}{l}\text { Standar } \\
\text { dized } \\
\text { Coeffici }\end{array}$ & \multirow{2}{*}{$\mathrm{t}$} & \multirow{2}{*}{ Sig. } \\
\hline & B & $\begin{array}{l}\text { Std. } \\
\text { Error }\end{array}$ & Beta & & \\
\hline (Constant) & 3.878 & .288 & & 13.446 & .000 \\
\hline X1 & .000 & .004 & .016 & .126 & .900 \\
\hline $\mathrm{X} 2$ & .001 & .003 & .022 & .171 & .864 \\
\hline
\end{tabular}

a. Dependent Variable: Y1

Sumber data primer yang diolahtahun 2017

- Konstanta sebesar 3,878 menyatakan bahwa jika variabel $\mathrm{X} 1$ dan $\mathrm{X} 2$ tidak ada, maka nilai Y1 adalah sebesar 3,878

- Koefisien regresi X1 sebesar 0,000 menyatakan bahwa setiap kenaikan $\mathrm{X} 1$ sebesar 1\% maka nilai Y1 akan meningkat sebesar 0,000 , sedangkan untuk koefisien regresi X2 sebesar 0,001 menyatakan bahwa setiap kenaikan X2 sebesar $1 \%$ maka nilai Y1 akan meningkat sebesar 0,001

Tabel 4.14

Regression (Regresi Variabel X1 dan X2 terhadap Y2)

Descriptive Statistics

\begin{tabular}{|c|c|c|c|}
\hline & Mean & Std. Deviation & $\mathrm{N}$ \\
\hline Y2 & 73.1154 & 9.13260 & 65 \\
X1 & 54.9615 & 8.69955 & 65 \\
X2 & 54.7308 & 9.70385 & 65 \\
\hline
\end{tabular}

Sumber data primer yang diolah 2017

\begin{tabular}{|c|c|c|c|c|c|c|c|c|c|}
\hline \multicolumn{10}{|c|}{ Model Summary $^{\mathbf{b}}$} \\
\hline & & $\mathrm{R}$ & $\mathrm{R}$ \\
Squarel & $\begin{array}{c}\text { Adjust } \\
\text { ed R } \\
\text { Square }\end{array}$ & $\begin{array}{c}\text { Std. Error } \\
\text { of the } \\
\text { Estimate }\end{array}$ & $\begin{array}{c}\mathrm{c} \\
\text { Square } \\
\text { Change }\end{array}$ & $\begin{array}{c}\mathrm{F} \\
\text { Change }\end{array}$ & Df 11 & df2 & $\begin{array}{c}\text { Sig. F } \\
\text { Change }\end{array}$ \\
\hline 1 & $.758^{\mathrm{a}}$ & .575 & .561 & 6.04821 & .575 & 41.960 & 2 & 62 & .000 \\
\hline
\end{tabular}

a. Predictors: (Constant), X2, X1

b. Dependent Variable: Y2

Sumber data primer yang diolah

$$
2017
$$

Angaka R (koefisien korelasi) sebesar 7,58 menyatkan bahwa hubungan antara Y2 dengan variabel independent (X1 dan X2) adalah sebesar 7,58. Angka $\mathrm{R}$ Square (koefisien determinasi) adalah 5,75 yang didapat dari pengkuadratan koefisien $5,75 \mathrm{x}$ 5,75 . Hal ini berarti bahwa $1 \%$ variasi dari Y2 tidak bisa dijelaskan oleh variasi dari variabel $\mathrm{X} 1$ dan X2 sedangkan sisanya sebesar $99 \%$ dijelaskan oleh variabel lain

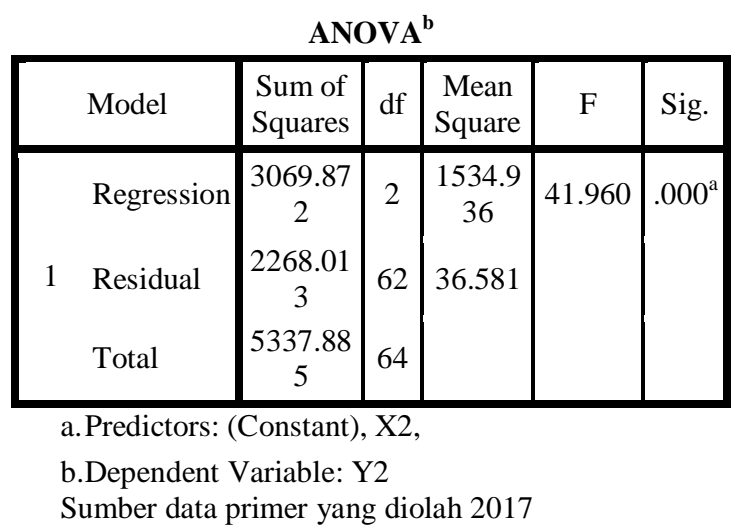


Dari Uji Anova atau F test, didapat F hitung sebesar 41,960 dengan tingkat signifikan 0,000. Karena probabilitas jauh lebih kecil dari 0,05, maka model regresi bisa dipakai untuk memprediksi Y2 atau bisa dikatakan bahwa X1 dan $\mathrm{X} 2$ berpengaruh terhadap Y2.

Variabel X1 dan X2 mempunyai angka signifikan lebih kecil dari 0,05, Oleh karena itu variabel tersebut berpengaruh (signifikan secara statistic) terhadap Y2

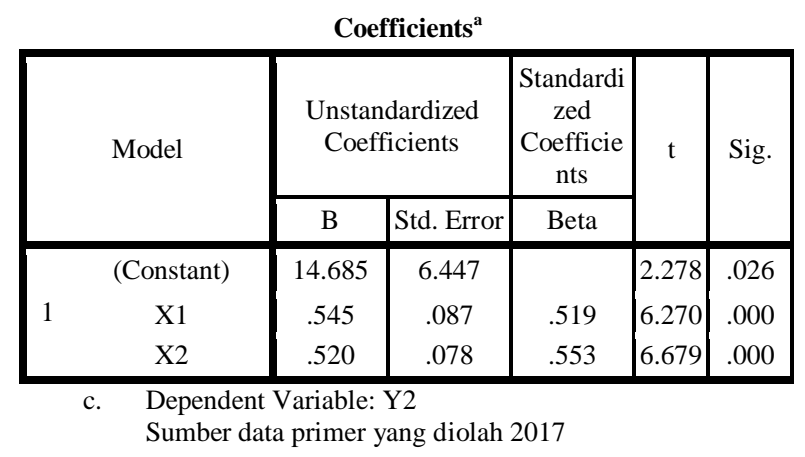

- Konstanta sebesar 14,685, menyatakan bahwa jika variabel $\mathrm{X} 1$ dan $\mathrm{X} 2$ tidak ada maka nilai Y2 adalah 14,685.

- Koefisien regresi X1 sebesar 545, menyatakan bahwa setiap kenaikan X1 sebesar 1\% maka nilai Y2 akan meningkat sebesar 545

- Sedangkan koefisien regresi X2 sebesar 520,menyatakan bahwa setiap kenaikan X2 sebesar $1 \%$ maka nilai Y2 akan meningkat sebesar 5

Tabel 4.15

Uji Anova (Variabel X1, X2, Y1 terhadap Y2)

\section{Descriptive Statistics}

\begin{tabular}{|c|c|c|c|}
\hline & Mean & $\begin{array}{c}\text { Std. } \\
\text { Deviation }\end{array}$ & N \\
\hline Y2 & 73.1154 & 9.13260 & 65 \\
X1 & 54.9615 & 8.69955 & 65 \\
\hline
\end{tabular}
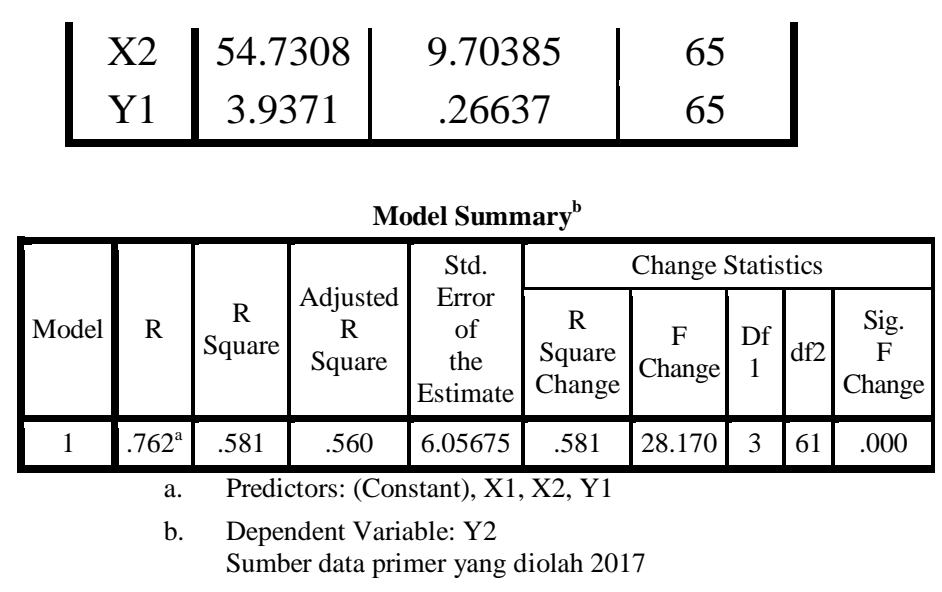

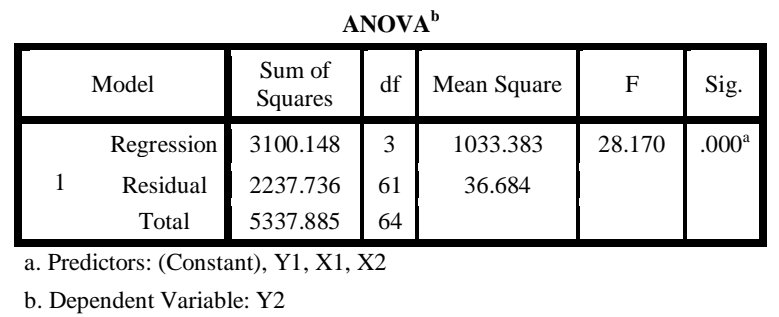

Dari Uji anova atau F test, didapat F hitung sebesar 28,170 dengan tingkat signifikan 0,000 . Karena probabilitas jauh lebih kecil dari 0,05 maka model regresi bisa dipakai untuk memprediksi Y2 atau bisa dikatakan bahwa X1,X2 dan Y1 berpengaruh terhadap Y Tabel 4.16

Uji t (Variabel X1,X2 dan Y1 terhadap Y2)

$$
\text { Coefficients }^{\mathrm{a}}
$$

\begin{tabular}{|c|c|c|c|c|c|c|}
\hline & \multirow[t]{2}{*}{ Model } & \multicolumn{2}{|c|}{$\begin{array}{l}\text { Unstandardized } \\
\text { Coefficients }\end{array}$} & $\begin{array}{l}\text { Standardized } \\
\text { Coefficients }\end{array}$ & \multirow[t]{2}{*}{$\mathrm{t}$} & \multirow[t]{2}{*}{ Sig. } \\
\hline & & B & Std. Error & Beta & & \\
\hline \multirow{4}{*}{1} & (Constant) & 24.701 & 12.776 & & 1.933 & .058 \\
\hline & $\mathrm{X} 1$ & .546 & .087 & .520 & 6.275 & .000 \\
\hline & $\mathrm{X} 2$ & .522 & .078 & .555 & 6.688 & .000 \\
\hline & Y1 & -2.583 & 2.843 & -.075 & -.908 & .367 \\
\hline
\end{tabular}

Berdasar Uji t, di dapat nilai $\mathrm{t}$ hitung untuk X1 sebesar 6,275, X2 sebesar 6,688 dan Y1 sebesar 9,08 berarti nilai $\mathrm{t}$ hitung lebih besar dari $\mathrm{t}$ table $(0,05)$ maka hipotesis alternatif diterima dan hipotesis nihil ditolak.

Sedangkan nilai signifikan 
$\mathrm{X} 1(0,000)<0,05$

$\mathrm{X} 2(0,000)<0,05$

$\mathrm{Y} 1(3,67)>0,05$

Dari Uji t atau $\mathrm{t}$ tes, variabel $\mathrm{X} 1$ dan $\mathrm{X} 2$ berpengaruh (signifikan secara statistik) terhadap Y2. Sedangkan Variabel Y1 tidak berpengaruh (tidak signifikan secara Statistik) terhadap Y2.

\subsection{Uji Hipotesis Penelitian}

\section{a. Motivasi Belajar}

Berdasarkan perhitungan Uji t, didapat angka signifikan diatas 0,05 atau nilai $t$ hitung $\left(t_{0}\right)$ lebih besar dari $t$ tabel $\left(t_{t}\right)$ maka hipotesis nol diterima dan hipotesis alternatif ditolak. Hal ini bearti bahwa penggunaan multimedia interaktif tidak berpengaruh (tidak signifikan secara statistic) terhadap motivasi belajar. Hasil lain ditunjukan dari nilai probabilitas $0,978>0,05$, Terdapat perbedaan motivasi belajar yang tidak signifikan antara siswa yang memanfaatkan multimedia interaktif dengan siswa yang mendapatkan pembelajaran konvensional.Walaupun secara statistik tidak signifikan namun terdapat kencendrungan terjadi peningkatan antara rata-rata nilai pre tes dan rata-rata nilai pos tes baik pada kelas eksperimen maupun kelas kontrol.

b. Hasil Belajar kognitif

Berdasarkan uji t, didapat angka signifikan 0,000 lebih kecil dari 0,05 Atau nilai $t$ hitung $\left(t_{0}\right)$ lebih kecil dari tabel $\left(t_{t}\right)$ maka hipotesis nol Diterima dan hipotesis alternatif ditolak. Hal ini berarti bahwa penggunaan Multimedia Interaktif berpengaruh terhadap kemampuan kognitif siswa.Hasil lain ditunjukan dari nilai probabilitas strategi $0,000<$ 0,05 sehingga. Dapat dikatakan bahwa terdapat perbedaan hasil belajar kognitif yang signifikan antara siswa yang memanfaatkan multimedia interaktif dengan siswa yang mendapatkan pembelajaran melalui strategi konvensional.

c. Multimedia Interaktif dan motivasi

Dari Uji anova atau $\mathrm{F}$ test, didapat $\mathrm{F}$ hitung sebesar 28,170 dengan tingkat signifikan 0,000 . Karena probabilitas jauh lebih kecil dari 0,05 maka model regresi bisa dipakai untuk memprediksi Y2 atau bisa dikatakan bahwa X1, X2 dan Y1 berpengaruh terhadap Y2.

Berdasarkan uji t didapat angka signifikan variabel $\mathrm{X} 1$ dan $\mathrm{X} 2$ 0,000 lebih kecil dari 0,05 berarti variabel X1 dan X2 Berpengaruh terhadap Y2 sedangkan angka signifikan Y1 terhadap Y2 sebesar 3,67 lebih besar dari 0,05. Terdapat pengaruh multimedia interaktif terhadap hasil belajar kognitif. Tidak terdapat pengaruh motivasi terhadap hasil belajar kognitif.

Hal ini berarti tidak terdapat interaksi penggunaan multimedia interaktif IPA-Biologi dan motivasi terhadap kemampuan kognitif siswa

\section{KESIMPULAN DAN SARAN}

\subsection{Kesimpulan}

Berdasarkan analisis data hasil pembahasan dapat diperoleh kesimpulan sebagai berikut:

1. Multimedia interaktif sebagai media pembelajaran tidak berpengaruh terhadap motivasi belajar biologi siswa. Hal ini dapat dilihat dari angka signifikan di atas 0,05.Hasil lain ditunjukkan dari nilai probabilitas strategi $0,978>0,05$, jadi terdapat perbedaan motivasi belajar yang tidak signifikan antara siswa yang memanfaatkan Multimedia interaktif dengan siswa yang mendapatkan 
pembelajaran melalui strategi konvensional. Namun terdapat kecendrungan peningkatan rataratanilai motivasi yang lebih tinggi pada kelas eksperimen daripada Kelas control

2. Multimedia interaktif sebagai media pembelajaran berpengaruh terhadap hasil belajar kognitif siswa. Hal ini ditunjukkan dari angka signifikan lebih kecil dari 0,05 . Hasil lain ditunjukan dari nilai probabilitas strategi $0,000<$ 0,05 Sehingga dapat dikatakan bahwa terdapat perbedaan hasil belajar kognitif yang signifikan antara siswa yang memanfaatkan Multimedia interaktif dengan siswa yang mendapatkan pembelajaran melalui strategi konvensional.

3. Multimedia Interaktif dan motivasi secara bersama-sama mempengaruhi kemampuan kognitif siswa.hal ini ditunjukkan dengan nilai probabilitas strategi $0,000<0,05$.

\subsection{Saran-Saran}

Berdasarkan hasil penelitian diajukan saran sebagai berikut:

1. Guru bidang studi dapat memanfaat Multimedia interaktif sebagai media pembelajaran biologi yang dapat dipadukan dengan strategi pembelajaran yang lain. Karena terbukti keberhasilannya untuk meningkatkan hasil belajar kognitif.

2. Dapat dilakukan penelitian lanjutan dengan memanfaatkan Multimedia interaktif yang dapat digunakan untuk mengukur hasil belajar afektif, psikomotorik atau kemampuan yang lain seperti metakognitif dan berpikir kritis.

3. Dalam pembelajaran, guru diharapkan dapat memberikan pengalaman pembelajaran yang baru untuk meningkatkan motivasi dan hasil belajar siswa

4. Diharapkan Multimedia interaktif dapat digunakan sebagai alternatif media pembelajaran biologi disamping media pembelajaran yang lain.

5. Dapat dilakukan penelitian lagi dengan populasi yang lebih luas agar dapat dimanfaatkan disekolah-sekolah yang lain.

\subsection{Implikasi Manajerial}

Dari hasil analisa secara garis besar penggunaan multimedia interaktif tidak berpengaruh terhadap motivasi tetapi penggunaan multimedia interaktif berpengaruh terhadap kemampuan kognitif siswa. Dengan kata lain Multimedia interaktif tidak meningkatkan motivasi dan secara tidak langsung tidak meningkatkan kemampuan kognitif siswa. Hal ini terjadi karena motivasi belajar dan kemampuan kognitif siswa dapat dipengaruhi oleh banyak faktor bukan hanya pengunaan media saja. Ada faktorfaktor lain yang dapat mempengarui, seperti faktor lingkungan dan kondisi belajar, kondisisiswa padasaat proses pembelajaran berlangsung, variasi guru mengajar,teknik guru mengajar, metode mengajar guru. Intinya media hanyalah sebagai alat bantu mengajar dan tidak bisa menggantikan posisi guru, guru tetap memiliki peran yangutama dalam meningkatkan kemampuan kognitif dan motivasi siswa dalam belajar.

Perhatian siswa didorong rasa ingin tau. Rasa ingin tau perlu mendapat rangsangan sehingga siswa akan memberi perhatian dan perhatian tersebut terpelihara selama berlangsungnya pembelajaran. Menurut Kellough dalam Sumarno (2011) dalam kegiatan belajar mengajar peran guru yang sangat penting dalam mendorong 
pembelajaran siswa adalah meningkatkan keinginan siswa atau memotivasi siswa untuk belajar. Dalam melakukan tugas tersebut guru perlu memahami siswa dengan baik agar nantinya guru mampu menyediakan pengalamanpengalaman pembelajaran, yang darinya siswa menemukan sesuatu yang menarik, bernilai, dan secara intrinsic memotivasi, menantang, dan berguna bagi mereka.

\section{DAFTAR PUSTAKA}

Aina, Mia, 2012, Efektifitas Pemanfaatan Multimedia Interaktif Pembelajaran IPA- Bilogi dalam Meningkatkan Motivasi Belajar siswa pria dan wanita SMP 19 Kota Jambi, Tesis Universitas Jambi.

2013, Pengaruh Pemanfaatan Multimedia Interaktif Pembelajaran IPA-Biologi Terhadap Motivasi dan Kemampuan Kognitif Siswa SMP 19 Jambi,Tesis Universitas Jambi.

Afrian, Rio, dkk, 2013, Pengaruh Peembelajaran Multimedia Interaktif Terhadap Hasil Belajar, Lampung, Tesis Universitas Lampung.

Alim Sumarno, 2011, Teori Motivasi dan Pengukuran Analisis di Bidang Pendidikan, https:// elearning, unesa.ac.ad/myblog/ Jurnal Alim Sumarno mei 2011.

Ancok, Djamaludin,. 1989, Validitasdan Reliabilitas Intrumen Penelitian, Jakarta: LP3ES.

Amelia, Dwi Risky, 2016, Pengaruh Penggunaan Multimedia Interaktif Terhadap Hasil belajar Siswa Pada Mata pelajaran Bahasa Arab Di Kelas X SMA Muhammadyah 6
Palembang, Tesis Universitas Islam Negeri Palembang.

Arikunto, Suharsimi, 2006, Prosedur Penelitian Suatu PendekatanPraktik, Jakarta, Penerbit Rineka Cipta.

2008, Dasar-dasar Evaluasi Pendidikan Edisi.2, Jakarta, Penerbit Bumi Aksara.

Arsyad, Azhar, 2010, Media Pembelajaran, Yogyakarta, Penerbit PT.Raja Grafindo Persada.

Astaqauliyah, 2006, Teori Motivasi dan Pemgukuran Analisis di Bidang Pendidikan, Astaqauliyah.com.

Candra, A.Evi, 2012, Pengaruh Media Pembelajaran interaktif melalui Siklus Belajar Terhadap Motivasi dan Hasil Belajar,Tesis Universitas Malan.

Daryanto, 2016, Media Pembelajaran Peranannya Sangat Penting Dalam Tujuan Pembelajaran, Yogyakarta, Penerbit Gava Media.

Dewi, Arfita Restu Kurnia, 2011, Analisa Dan Perancangan Aplikasi Multimedia Pembelajaran Biologi Untuk SMA. Kelas X, Yogyakarta, Sekolah Tinggi Manajemen Informatika dan Computer.

Dimyanti dan Mudjono, 2006, Belajar dan pembelajaran. Jakarta: Rineka Cipta.

....., 2009. Belajar dan pembelajaran. Jakarta: Rineka Cipta.

Djali, H.P dan Muljiono, 2007, Pengukuran dalam Bidang Pendidikan, Jakarta, PT.Grasindo.

Djamarah S.B, 2008, Psikologi Belajar, Edisi 2, Jakarta, Rineka Cipta. 
Faturrohman, 2007, Strategi Belajar Mengajar, Bandung, Penerbit PT. Rafika Aditama.

Hamalik, Oemar, 2011, Media Pendidikan, Bandung: Citra Aditya Bakti.

Hamalik, Oemar (2001) Proses Belajar Mengajar. Jakarta: Rineka Cipta.

Herlina, 2014, Pengaruh Penggunaan Multimedia Interaktif Terhadap Minat Belajar Mahasiswa Pada STMIK handayani Makassar, Jurnal Penelitian komunikasi dan Opini Publik Vol.18 no.3, Desember 2014;241-254.

Husein, Sadam, dkk, 2013, Pengaruh Penggunaan Multimedia Interaktif Terhadap Penguasaan Konsep dan ketrampilan Berpikir Kritis Siswa pada materi Suhu Dan kalor, Jurnal pendidikan Fisika dan Teknologi (ISSN 2407-6902).

Kartikasari, Galuh, 2016, Pengaruh Media Pembelajaran Berbasis Multimedia Terhadap Motivasi Dan Hasil Belajar Materi Sistem Pencernaan Manusia, Jurnal Penelitian Vol.16, No.1, 2016, Sekolah Tinggi Agama Islam Miftahul Ula Kertasono.

Kasiono Trans, dkk, Pengaruh Penggunaan Multimedia, Sumber Belajar, Nilai Karakter Terhadap Hasil belajar Tesis Universitas lampung.

Muklis, 2010, Efektifitas Pembelajaran Bahasa Arab Menggunakan Multimedia Di Kelas XI Madrasah Aliyah Swasta Raudhatul Ulum, Sakatiga indralaya Ogan Ilir, Tesis, Institut Agama Islam Negeri Palembang.
Mulyati, https://www tokopedia.com/took buku/Teori Motivasi dan Pengukuran.

Motivasi Belajar, 2015, Angket Motivasi Belajar Setiap Mata Pelajaran: http://www.belajar bagus. Net/2015/04/angket-motivasibelajar.html

Peraturan Menteri Pendidikan Dan Kebudayaan Republik Indonesia Nomor 104 Tahun 2014 Pasal 1 Nomor 3 tentang Penilaian Hasil Belajar Oleh Pendidikan Dasar dan Pendidikan Menengah.

Permendikbud, No.53 tahun 2015, Panduan Penilaian Untuk Sekolah Menengah Pertama.

Rencana Strategis Kementrian Pendidikan Nasional 2010-2014 Diakses tanggal November 2015

Riduwan,2004, statistik untuk lembaga dan Instansi Pemerintah/Swasta, Penerbit Afabeta Bandung.

Rusman, 2012, Belajar dan pembelajaran Berbasis Multimedia, Penerbit Alfabeta Bandung, 332 hlm.

Saiful, 2008, Kompetensi Mengajar Guru Biologi Dan Pengaruhnya Terhadap Prestasi Belajar siswa Madrasah Aliyah Negeri, Kota Palembang (Penerapan Multimedia Pada Pembelajaran Ekresi), Tesis Institut Agama Islam Negeri(IAIN) Palembang.

Sani, A. Ridwan, 2014, Inovasi pembelajaran, Jakarta, Penerbit PT.Bumi Aksara 314 hlm.

Sardiman A. M, 2007, Interaksi dan Motivasi Belajar Mengajar, Jakarta, Raja Grafindo. 
Slavin, R, E, 1995 Cooperatip Learning: Theory,Reseach, and Practice Secoun Edition. Massachusett: Allyln and Bacon.

Sudijono, Anas, 2010, Pengantar Statistik Pendidikan, Jakarta rajawali Pers.

Sudrajat, A, https://Akhmad Sudrajat Wordpress.com/ 2008/02/06/ Jurnal Teori - teori Motivasi dan Pengukuran di Bidang Pendidikan.

Sugiono, 2009, Metode Penelitian Tindakan Kelas Pendekatan Kuantitatif, Kualitatif dan R\&D. Bandung: Penerbit Alfabeta.

Sugiono, 2009, Metode Penelitian Kuantitatif, kualitatif dan R\&D, Bandung: Penerbit Alfabeta.

Sugiyono, 2013, Metode Penelitian Kombinasi, Bandung: Penerbit Alfabeta. ,2007, Statistik Untuk penelitian, Bandung, Penerbit Alfabeta.

Soekidjo Notoatmodjo, 2010, Teori dan Aplikasi, edisi revisi, Jakarta, Rineka Cipta.

Sumarno, https://

Sumarnowordpress.com/2011/

Jurnal Teori - teori Motivasi dan pengukuran Analisis di Bidang Pendidikan.

Sumiati dan Asra, 2009, Metode Pembelajaran, Bandung, CV. Wacana Prima.

Sutarno, 2011, Penggunaan Multimedia Interaktif, pada pembelajaran medan magnet untuk meningkatkan keterampilan berfikir generik sains mahasiswa. Jurnal Exacta Vol IX (1).
Suparno, Paul, 2001, Teori Perkembangan Kognitif Jean Piaget, Yoogyakarta: Penerbit Karnisius.

Uno, H.B. (2006). Teori Motivasi dan Pengukuran, Jakarta, Bumi aksara.

Tangkas, I Made, 2012, Pengaruh Implementasi model Pembelajaran Inkuari Terbimbing Terhadap Kemampuan Pemahaman Konsep Dan ketrampilan Proses sains Siswa kelas X SMA 3, Amlapura, Tesis Universitas Pendidikan Ganesha.

Umti'ah, 2012, Penerapan Multimedia Pembelajaran Terhadap Peningkatan Hasil Belajar Siswa Mata Pelajaran Al- Islam Di Sekolah Menengah Atas Muhammadyah 2, Palembang, Tesis Institut Agama Islam Negeri Raden fatah Palembang.

Vony, 2015, Pengaruh Media Pembelajaran Multimedia Interaktif Terhadap Hasil Belajar Hakikat Geografi Ditinjau Dari Tingkat Motivasi Belajar Geografi Siswa Kelas X IPS. SMA Negeri 2, Jayapura, Tesis Universitas Sebelas Maret Surakarta.

Zamzam, Fakhry, 2015, Teknik Dasar Menulis Proposal Tesis, Palembang, Penebit Noer Fikri. 